\title{
UNRAVELING MONOAMINE RECEPTORS INVOLVED IN THE ACTION OF TYPICAL AND ATYPICAL ANTIPSYCHOTICS ON GLUTAMATERGIC AND SEROTONERGIC TRANSMISSION IN PREFRONTAL CORTEX
}

\author{
Xavier López-Gil ${ }^{1,2}$, Francesc Artigas ${ }^{1,2}$ and Albert Adel1 ${ }^{1,2 *}$ \\ ${ }^{1}$ Department of Neurochemistry and Neuropharmacology, Instituto de \\ Investigaciones Biomédicas de Barcelona, CSIC (IDIBAPS), Barcelona, Spain \\ ${ }^{2}$ Centro de Investigación Biomédica en Red de Salud Mental (CIBERSAM)
}

Running title: Monoamine receptors and antipsychotic action

"Corresponding author:

Albert Adell, Ph.D.

Department of Neurochemistry and Neuropharmacology

Instituto de Investigaciones Biomédicas de Barcelona, CSIC (IDIBAPS)

Carrer Rosselló 161, 6th floor, Room 630

E-08036 Barcelona, Spain

Phone: +34 933638321

Fax: +34 933638301

E-mail: aacnqi@iiibb.csic.es 


\section{INTRODUCTION}

The NMDA receptor hypofunction hypothesis of schizophrenia was established after the observation that NMDA receptor antagonists such as phencyclidine (PCP) and ketamine can induce, in healthy individuals, altered behavioral states that resemble the positive and negative symptoms as well as the cognitive deficits seen in schizophrenia [1-3]. In addition, ketamine can heighten psychotic episodes in patients with schizophrenia [4-6]. In rodents, PCP and the more potent and selective noncompetitive NMDA receptor antagonist, dizocilpine (MK-801), cause hyperlocomotion and stereotypies [7-9]. The hyperactivity is considered to be due predominantly to activation of $D_{2}$ receptors in the nucleus accumbens, whereas stereotypies are caused by stimulation of $D_{2}$ receptors in the caudate-putamen [10]. These behaviors have been potentially related to positive symptoms of schizophrenia [11-13]. Acute NMDA receptor antagonism has also been reported to increase the release of glutamate [14-18], dopamine [19, 20], and serotonin (5-HT) [8, 16-18, 21, 22] in the medial prefrontal cortex (mPFC). It has been proposed that stimulation of NMDA receptors on the GABA inhibitory interneurons within the cortex leads to the release of GABA, which would inhibit glutamatergic neurons and the subsequent release of glutamate. Blockade of such NMDA receptors would therefore decrease GABAergic inhibitory tone and result in an enhanced activity of pyramidal neurons within the cortex $[14,23,24]$ leading to downstream changes in other transmitters. Indeed, GABAergic interneurons in limbic cortex and hippocampus are more sensitive than pyramidal neurons to the action of NMDA receptor antagonists $[25,26]$. In addition, reduced GABAergic function would alter the synchronous firing patterns of cortical neurons, which may underlie information-processing deficits present in patients with schizophrenia [27].

Various studies have demonstrated that the interactions among dopamine, 5-HT and glutamate play an important role in the pathophysiology of schizophrenia and that receptors for these transmitters are involved in the action of antipsychotic drugs. Increased activity of the mesolimbic dopamine system is believed to underlie the positive or psychotic symptoms of 
schizophrenia and decreased activity within the mesocortical dopamine system is believed to reflect negative symptoms and cognitive function also seen in this illness [28-32]. All available antipsychotic drugs posses some degree of dopamine $D_{2} / D_{3}$ receptor antagonism, and blockade of dopamine $D_{2} / D_{3}$ receptors within the mesolimbic pathway reduces psychotic symptoms [33]. As a matter of fact, a good correlation exists between the clinical efficacy of antipsychotic drug and their affinity for $D_{2}$ receptor [34, 35]. Furthermore, most antipsychotic drugs display a dose-dependent threshold of $D_{2} / D_{3}$ receptor occupancy for their therapeutic effects [36]. However, the necessity of $D_{2} / D_{3}$ receptor blockade for therapeutic action has been challenged recently by the finding that drugs that attenuate glutamate release, without acting directly on dopamine receptors, are beneficial for positive and negative symptoms [37].

Several atypical antipsychotic drugs, on the other hand, are characterized by a lower affinity for $\mathrm{D}_{2} / \mathrm{D}_{3}$ and higher affinity for $5-\mathrm{HT}_{2 \mathrm{~A}}$ receptors, which has been proposed to confer a superior efficacy and tolerability $[38,39]$. The lower occupancy of dopamine $D_{2} / D_{3}$ receptors appears to be responsible for causing fewer extrapyramidal side-effects (EPS) [40]. In addition to the predominant role of the $D_{2} / D_{3}$ receptor in the current treatment of psychotic symptoms, dopamine $D_{1}$ receptors have been implicated in schizophrenia [41, 42]. This line of evidence has been recently highlighted by the finding that cognitive/negative symptoms in schizophrenia are associated with a reduction of prefrontal dopamine $D_{1}$ receptor binding [43]. Some atypical antipsychotic drugs may also have affinity for other transmitter receptors such as serotonin $5-H T_{1 A}, \alpha$-adrenergic, histamine $H_{1}$, and muscarinic receptors, which may affect their efficacy and side-effect profile [44, 45]. Thus, there is some evidence for the importance of $5-\mathrm{HT}_{1 \mathrm{~A}}$ receptor agonists in certain aspects of the pharmacotherapy of schizophrenia [46-49]. Furthermore, 5- $\mathrm{HT}_{1 \mathrm{~A}}$ receptor agonists have been shown to reduce the incidence of EPS in schizophrenia patients treated with haloperidol $[50,51]$. With regard to $\alpha-$ adrenergic mechanisms, many clinically effective antipsychotic drugs (both classical and atypical) possess $\alpha_{1}$-adrenoceptor antagonist properties [44, 52], which has been postulated to be clinically relevant [53]. However, although 
central $\alpha_{1}$-adrenoceptors may regulate sensorimotor gating altered in schizophrenia [54], there are not studies dealing with the occupancy of $\alpha_{1}$ adrenoceptors in individuals under antipsychotic treatment.

In the animal setting, most studies have shown that atypical, but not typical, antipsychotics block the effects of NMDA receptor antagonists on prepulse inhibition (PPI) of the startle response [55]. In addition, atypical antipsychotic drugs, but not haloperidol, increases extracellular DA concentration in the PFC $[56,57]$ and prevent the brain increase in regional 2deoxyglucose uptake induced by ketamine [58]. We have shown recently that the local perfusion of antipsychotic drugs decreased extracellular $5-\mathrm{HT}$ in the mPFC $[59,60]$. Stimulation of $5-\mathrm{HT}_{1 \mathrm{~A}}$ and blockade of $5-\mathrm{HT}_{2 \mathrm{~A}}$ receptors might contribute to this effect since both types of compounds were able to prevent the increases in 5-HT and glutamate, as well as cognitive deficits induced by NMDA receptor antagonists [16, 17, 61, 62]. In contrast, raclopride and eticlopride (dopamine $D_{2} / D_{3}$ antagonists) and SKF 38393 (dopamine $D_{1} / D_{5}$ agonist) prevented the increase of glutamate (but not that of 5-HT) induced by MK-801 [62]. Furthermore, clozapine and haloperidol attenuated PCP-induced increase in cortical glutamate [63], as well as the elevated firing of a population of mPFC pyramidal neurons elicited by PCP or MK-801 [64, 65]. Interestingly, clozapine exhibited a leveling effect on the firing of pyramidal cells in the mPFC, increasing the activity of neurons with low baseline firing rates and decreasing the activity of neurons with higher firing rates [64]. This fine-tuning effect might contribute to the unique therapeutic efficacy of clozapine in schizophrenia.

In a previous study we showed that both clozapine and haloperidol blocked the MK-801-induced increase in glutamate in rat MPFC, whereas only clozapine was able to block the increased efflux of 5-HT [18]. In addition, we also showed that antagonism at dopamine $D_{2}$ receptors and agonism at dopamine $D_{1}$ receptors resulted in blockade of the effects of MK-801 on MPFC glutamate but not $5-\mathrm{HT}$. In contrast, $5-\mathrm{HT}_{2 \mathrm{~A}}$ and $\alpha_{1}$-adrenergic receptor antagonists, as well as $5-\mathrm{HT}_{1 \mathrm{~A}}$ receptor agonist, were able to prevent the increase in 5-HT and glutamate elicited by MK-801 [62]. In the present study we set out to replicate such findings using a wider range of concentrations and 
extend them to other typical (chlorpromazine) and atypical (olanzapine) antipsychotic drugs. To this end, intracerebral microdialysis in the mPFC was used under the same experimental conditions described previously [18,63]. The choice of prefrontal cortex was accounted for by its pivotal involvement in higher brain functions such as executive tasks and cognition [66] known to be disrupted in schizophrenia [67] and in animal models [68]. Despite the importance of mPFC in the etiology and pharmacotherapy of schizophrenia, it is worth noting that the effects of such compounds in other brain regions may also be crucial for the treatment of the illness. From a methodological point of view it is also important to note that antipsychotic drugs and selective compounds were delivered in the mPFC by reverse dialysis. Despite the in vitro affinity $\left(10^{-8}-10^{-9}\right.$ M) of antipsychotics and selective compounds used in the present study for serotonergic and adrenergic receptors, the use of concentrations in the micromolar range is required in in vivo microdialysis to significantly affect neurotransmitter receptors (e.g. $[69,70]$ ). This is due to the fact that effective concentration at receptors is limited by the low application rate (in the low $\mathrm{nmol} / \mathrm{h}$ range) and the continuous clearance of the applied drug by the cerebrospinal fluid. Moreover, a substantial number of post-synaptic receptors in mPFC neurons must be recruited to activate/inhibit the mPFC-raphe circuit and elicit changes in mPFC 5-HT release $[71,130]$.

\section{IS CORTICAL 5-HT TRANSMISSION RELATED TO “ATYPICALITY”?}

The term "atypical" referred to an antipsychotic drug was first applied to clozapine because this drug was devoid of the overt EPS and increased prolactin secretion seen in humans treated with neuroleptics. By comparison with the pharmacological profile of clozapine, it is considered that atypical antipsychotic drugs are relatively more potent serotonin $5-\mathrm{HT}_{2 \mathrm{~A}}$ antagonists than dopamine D2 antagonists (see [39] for review). More recently, the multireceptor pharmacology of atypical antipsychotics has included other features such as serotonin 5- $\mathrm{HT}_{1 \mathrm{~A}}$ and dopamine D1 agonism, dopamine D2 partial agonism as well as $\alpha_{1}$-adrenergic antagonism $[46,53,72,73]$. 
The effects of antipsychotic drugs on extracellular 5-HT in the MPFC are far from conclusive $[18,61,74,75]$. In general, both typical and atypical antipsychotics seem to decrease or leave unchanged cortical 5-HT although the particular effect might depend on the experimental conditions and/or dose of the drug. However, there seems to be a concurrence of results showing that risperidone increases cortical dialysate $5-\mathrm{HT}$, an effect which is probably related to its antagonistic action at $\alpha_{2}$-adrenoceptor, and seems to take place at the nerve terminal level [74]. In line with this assumption, Hertel and coworkers [76] demonstrated that idazoxan, an $\alpha_{2}$-adrenoceptor antagonist, in combination with raclopride (dopamine $D_{2} / D_{3}$ receptor antagonist), exerted a clozapine-like antipsychotic effect on phencyclidine-treated animals. Thus, the role of mPFC 5-HT in the mechanism of action of atypical antipsychotic drugs appears equivocal. Nevertheless, a different issue that has been addressed in the present study is the role of cortical 5-HT in the action of antipsychotics in an animal model of schizophrenia.

Previous studies have demonstrated that NMDA receptor antagonists augment the firing rate of putative pyramidal neurons within the $\operatorname{mPFC}[65,77$, 78], which results in an increased efflux of glutamate and 5-HT. These effects are accounted for by an overstimulation of cortical AMPA-dependent glutamatergic transmission because they were abolished by intra-mPFC perfusion of an AMPA receptor antagonist [18, 79]. In line with previous research $[8,14,15]$, MK-801 increases glutamate release onto AMPA/kainate receptors leading to an enhanced glutamatergic output from mPFC neurons (including those projecting to the dorsal raphe nucleus) thereby increasing serotonergic cell firing and cortical 5-HT release. Furthermore, it has been shown that blockade of AMPA/kainate receptors in the prefrontal cortex inhibited PCP-induced locomotion and stereotypy [80]. The antipsychotic action would therefore result from a prevention of the effects resulting from this cortical hyperglutamatergia.

In an initial study carried out in our lab we showed that pretreatment with atypical antipsychotic drugs such as clozapine and olanzapine suppressed the increased release of $5-\mathrm{HT}$ in the mPFC elicited by phencyclidine (PCP) and 
ketamine whereas haloperidol failed to do so [22]. Subsequently we demonstrated that clozapine and haloperidol were able to block the increase in cortical glutamate produced by MK-801, but only clozapine reduced the increase in 5-HT [18]. In addition, the mPFC appeared to be the preferential site of action of these drugs inasmuch as their effects were seen after local infusion through a dialysis probe. As shown in Fig. (1), this differential action has been replicated and confirmed also for chlorpromazine (typical antipsychotic) and olanzapine (atypical antipsychotic). The fact that all four antipsychotic drugs tested are able to block the effect of MK-801 on extracellular glutamate is in line with recent results showing that both clozapine and haloperidol possess the ability to markedly inhibit a subset of mPFC neurons [64]. The most prominent features of the pharmacological profile shared by these antipsychotics are dopamine D2 receptor and $\alpha_{1}$-adrenoceptor antagonism [44, 45, 52, 81-83]. However, since prazosin can also prevent the increase in dialysate 5-HT produced by NMDA antagonists ([22]; Fig. (7) of this study), it was suggested that glutamatergic transmission in the mPFC is predominantly dependent on dopamine D2 receptors, but not on $\alpha_{1}$-adrenoceptors. Unlike the actions of clozapine and olanzapine, the lack of effect of haloperidol and chlorpromazine on cortical 5-HT points to a different regulation of the pyramidal cells projecting to the dorsal raphe nucleus (DR). Because only $5 \%$ of pyramidal neurons in layer $\mathrm{V}$ of the mPFC project to the dorsal raphe nucleus [84], it is conceivable that, under conditions of increased 5-HT and glutamate transmission in the mPFC following the administration of NMDA antagonists, blockade of D2 receptors by antipsychotic drugs might be able to inhibit cortical output (blockade of increased glutamate efflux), although sparing mPFC $\rightarrow$ DR projections. An alternative explanation could be that cortico-raphe projecting neurons might be inhibited by both typical antipsychotics, but not to the extent needed to suppress serotonergic firing distally in the DR and the subsequent cortical 5-HT release. On the other hand, we hypothesized that 5-HT concentration in the mPFC appears to be under the control of multiple monoamine receptors, which is coincident with the multi-receptor profile of atypical antipsychotics. 


\section{EFFECTS OF DOPAMINERGIC COMPOUNDS}

In accord with our hypothesis, we have shown that two different dopamine D2 receptor antagonists, raclopride and eticlopride, elicited the same effect than that of haloperidol and chlorpromazine ([62]; present study). Raclopride binds with equal affinity to $D_{2}$ and $D_{3}$ receptors and has negligible affinity for $D_{4}$ receptors [85], and eticlopride possesses equal selectivity for $D_{2}$ and $D_{3}$ receptors [86], but 10-fold greater affinity than raclopride for both receptors [87]. Eticlopride also interacts with $\mathrm{D}_{4}$ receptors [83]. It could be argued that the lack of effect of $D_{2} / D_{3}$ antagonists on cortical $5-H T$ can be accounted for by the low concentration of antagonists used. However, as shown in Fig (2), a higher concentration of raclopride $(100 \mu \mathrm{M})$ produced similar results, i.e. blockade of MK-801-induced effects on glutamate but not on $5-\mathrm{HT}$. Differences in the receptor populations present in layer $\mathrm{V}$ of the $\mathrm{mPFC}$ and the distinct pharmacological profile of clozapine, olanzapine, chlorpromazine and haloperidol (Table 1), could provide the anatomical substrate for this differential effect. Altogether, it appears that serotonergic transmission in the mPFC is regulated by the concurrent participation of multiple transmitter receptors, whereas glutamatergic transmission is strongly dependent on dopamine D2 receptor activation. Further evidence of the regulation of glutamate release in the mPFC by dopamine D2 receptors is provided by electrophysiological studies. Thus, the augmented efflux of dopamine elicited by the blockade of NMDA receptors [11, 19, 88] may promote dopamine D2-induced burst firing only in a small subset of pyramidal cells of the mPFC [89], possibly in those cells enriched in dopamine D2 receptors. However, dopamine D2 receptors are located not only in pyramidal cells, but also in GABA interneurons [90-93]. Further, tyrosine hydroxylase-positive terminals have been observed in apposition with GABA interneurons [94, 95]. Among the different types of cortical GABA interneurons, it has been shown that dopamine acts almost exclusively on those containing parvalbumin (PV) [92, 96], which target the perisomatic compartment of pyramidal cells [97, 98]. In addition, immunocytochemistry studies have reported that $\mathrm{PV}$ interneurons express both 
dopamine $D_{1}$ and $D_{2}$ receptors [92]. From a physiological viewpoint, dopamine exerts a tonic inhibitory action on PV interneurons through D2 receptors [99, 100]. In addition, evidence from a postmortem study has indicated that, in the anterior cingulate cortex of schizophrenics, there is a shift of dopaminergic terminals from pyramidal cells to GABA interneurons [101]. This dopamine could then act on D2 receptors located in these interneurons thereby reducing the release of GABA with the subsequent disinhibition of pyramidal cells. In the animal model setting that we used, an excessive release of dopamine following MK-801 administration [19] might lead to a further reduction in GABAergic inhibition, which would result in an impairment of the intrinsic cortical circuitry. In fact, this has been postulated to occur in the brain of schizophrenics [102-104]. Dopamine D2 antagonists would dampen the inhibitory action of dopamine overflow on GABA interneurons, thus elevating GABA release and reducing cortical glutamatergic output induced by MK-801. The relevance of PV interneurons in this process is underscored by two facts: 1) in rodents $50 \%$ of all GABA neurons contain PV [105] and 2) PV neurons are thought to play a predominant role in gamma oscillations [106-108]. A subtype of dopamine D2 receptor that has received attention recently is the $D_{4}$ receptor. The dopamine $D_{4}$ receptor is of interest because of its localization in limbic structures associated with the regulation of mood and cognition, such as cerebral cortex and hippocampus [109, 110]. In addition, clozapine and olanzapine have significant affinities at the dopamine $\mathrm{D}_{4}$ receptor (Table 1 ), which supports the role of this receptor as a potential target for antipsychotic drugs. For these reasons, it was deemed of importance to examine the effects of a dopamine $D_{4}$ receptor antagonist (L-745,870) on the MK-801-induced increases in cortical 5HT and glutamate. Intracortical pretreatment with L-745,870 prevented the effects of MK-801 on glutamate, but not those on 5-HT (Fig (3)). Although there is histological evidence of the presence of dopamine $D_{4}$ receptors in the mPFC of rodents, controversy exists as regards to the level of expression [91, 111115]. There is consensus, however, that the prefrontal cortex depicts a prominent expression of this receptor [91, 110,114, 115], which is expressed in both pyramidal and GABAergic cells [91, 110,114]. Our results are consistent 
with a localization of dopamine $D_{4}$ receptors in GABAergic interneurons although it remains to be determined the phenotype of such cells.

The regulation of prefrontal function by dopamine involves not only D2, but also D1 receptors. In fact, dopamine D1 agonists enhance cortical dopaminergic transmission, which is postulated to be good against cognitive and negative symptoms [116]. Indeed, the systemic administration of a low dose of a dopamine D1 receptor agonist ameliorates cognitive dysfunction induced by MK-801 although increases stereotypy and locomotor activity (model of psychotic symptoms) at higher doses [117]. Our results show that dopamine D1 agonism elicits comparable effects to those of dopamine D2 antagonists, i.e. a reduction of MK-801-induced increase of cortical glutamate [62]. However, when the concentration of the dopamine D1 agonist, SKF38393 , was increased to $100 \mu \mathrm{M}$, the elevation of $5-\mathrm{HT}$ elicited by MK-801 was abolished (Fig (4)). However, it remains to be determined the potential clinical relevance of this effect. Although dopamine $D_{1}$ receptors are expressed by deep layer cortical pyramidal neurons [93, 118, 119,], they are also localized to GABA-containing interneurons [92, 93, 119, 120]. Since the effect of SKF38393 is difficult to reconcile with an action on excitatory D1 receptors located on pyramidal neurons, a more plausible explanation is that SKF-38393 would bind to dopamine D1 receptors of GABAergic neurons, thereby turning on GABAergic inhibition, which would block the increase in glutamate efflux induced by MK-801. The dopamine D1 receptor family is comprised of two subtypes: $D_{1}$ and $D_{5}$. Inasmuch as the $D_{1}$ subtype seems to be predominant in cortical PV interneurons [120,121], it is conceivable that, in the conditions of the present study, the blockade of MK-801-induced increase in cortical glutamate is accounted for by an action of SKF-38393 on $D_{1}$ receptors located in PV interneurons. However, the blockade of the effects on 5-HT might also suggest the presence of $D_{1}$ receptors in another subpopulation of GABAergic interneurons that influence mPFC output to the raphe nuclei (Fig (8)).

Altogether our results suggest that D2 antagonists and D1 agonists might end up with the same response, i.e. to restore cortical GABA efflux in order to prevent an excessive glutamatergic transmission following MK-801 
administration. Furthermore, our results are also consistent with the proposal that D1 receptor activation requires phasic dopamine release whereas D2 receptors are continuously driven by basal, tonic dopamine release [122].

\section{EFFECTS OF SEROTONERGIC COMPOUNDS}

In contrast to dopamine D2 receptor antagonists, the selective $5-\mathrm{HT}_{2 \mathrm{~A}}$ antagonist, M100907 [123], prevented the increase in 5-HT and glutamate elicited by MK-801 in a concentration-dependent manner (Fig (5)). This agrees with prior work using a competitive NMDA receptor antagonist [16] and could reflect a reduction of a heightened prefrontal output (including that projecting to the DR) following MK-801. In fact, at the concentration of $300 \mu \mathrm{M}, \mathrm{M} 100907$ decreased MK-801-induced 5-HT level below baseline values. Previous work from our lab has also shown that $5-\mathrm{HT}_{2 \mathrm{~A}}$ antagonism is able to prevent other paradigms of higher serotonergic transmission in the $\mathrm{mPFC}$, such as intramPFC perfusion of S- $\alpha$-amino-3-hydroxy-5-methyl-4-isoxazole-4-propionic acid (S-AMPA), 2,5-dimethoxy-4-iodoamphetamine (DOI) and the $\alpha_{1}$-adrenoceptor antagonist cirazoline [59, 124], as well as thalamic disinhibition [60]. $5-\mathrm{HT}_{2 \mathrm{~A}}$ receptors are largely localized to apical dendrites of pyramidal neurons [125, 126], a cellular zone that receives inputs from different cortical areas, allowing integration within cortical layers and between different cortical areas. For this reason, $5-\mathrm{HT}_{2 \mathrm{~A}}$ antagonists are in a unique position to compensate for the increased cortico-cortical transmission that probably occurs after MK-801 administration and the pharmacological conditions mentioned above. Although there is evidence that $5-\mathrm{HT}_{2 \mathrm{~A}}$ receptors are also present in cortical GABAergic interneurons of the rat $\operatorname{mPFC}[125,127]$, our results points to a predominant effect of M100907 on the population of receptors located in pyramidal neurons following MK-801 administration.

Besides $5-\mathrm{HT}_{2 \mathrm{~A}}$ receptor antagonism, $5-\mathrm{HT}_{1 \mathrm{~A}}$ receptor agonism is also able to block the increase in 5-HT and glutamate elicited by MK-801 with a comparable potency ( $\mathrm{Fig}(6)$ ). Another study has shown that the $5-\mathrm{HT}_{1 \mathrm{~A}}$ receptor agonist 8-OH-DPAT also prevents the increase in cortical 5-HT and 
glutamate evoked by a competitive NMDA antagonist [17]. As for the effects of $\mathrm{M} 100907$, the reduction of $5-\mathrm{HT}$ is probably caused by a decrease in the activity of pyramidal cells projecting to the DR [128, 129], which would ease this nucleus from a tonic excitatory input, thereby decreasing the activity of 5-HT cells [130]. The 5-HT $1 \mathrm{~A}$ receptor agonist repinotan (BAY $x$ 3702) [131] has proved also effective in blocking the increased 5-HT release induced by intramPFC perfusion of S-AMPA, DOI and cirazoline [59, 124], as well as thalamic disinhibition [60]. The additional blockade of increased glutamatergic transmission suggests that $5-\mathrm{HT}_{1 \mathrm{~A}}$ receptor activation in the mPFC potently attenuates the action of agents that enhance the activity of pyramidal neurons, an effect shared by several different treatments and involving the stimulation of AMPA/kainate receptors in the $\operatorname{mPFC}[18,79]$. Furthermore, the crucial localization of $5-\mathrm{HT}_{1 \mathrm{~A}}$ receptors in the perisomatic domain of cortical pyramidal neurons of the rat prefrontal cortex [132] might explain the powerful effects of 5$\mathrm{HT}_{1 \mathrm{~A}}$ receptor agonists. Both $5-\mathrm{HT}_{2 \mathrm{~A}}$ and $5-\mathrm{HT}_{1 \mathrm{~A}}$ receptors show a $\sim 80 \%$ colocalization in the mPFC [124] with a high level of expression in pyramidal cells labeled by vGluT1 [127]. Altogether, this provides the anatomical support for an action of serotonergic compounds on pyramidal cells of the mPFC. Although 5$\mathrm{HT}_{2 \mathrm{~A}}$ and 5-HT $1 \mathrm{~A}$ receptors are also expressed in cortical GABAergic interneurons of the rat $[125,127,133]$, they do not seem to play a role in the control of cortical $5-\mathrm{HT}$ and glutamate in the conditions of the present work.

\section{EFFECTS OF $\alpha_{1}$-ADRENOCEPTOR ANTAGONISTS}

As for $5-\mathrm{HT}_{2 \mathrm{~A}}$ antagonists and $5-\mathrm{HT}_{1 \mathrm{~A}}$ agonists, the intra-mPFC administration of the $\alpha_{1}$-adrenoceptor antagonist prazosin [134] also blocked the MK-801induced increase in 5-HT and glutamate (Fig (7)). Although $\alpha_{1}$-adrenoceptors are largely co-expressed with $5-\mathrm{HT}_{2 \mathrm{~A}}$ receptors $(>80 \%)$ and are localized to both pyramidal and GABAergic cells (N. Santana, G. Mengod and F. Artigas, unpublished results) in the mPFC, the effects of prazosin seen in previous [62] and the present study are more congruous with a blockade of $\alpha_{1}$-adrenoceptors located on pyramidal neurons, including those in layer $V$ that project to the 
dorsal raphe nucleus. The mechanism of action of prazosin is most likely similar to that of M100907 inasmuch as both $5-\mathrm{HT}_{2 \mathrm{~A}}$ and $\alpha_{1}$-adrenoceptors are coupled to the same intracellular signaling mechanisms (phospholipase $C$ ) and mediate the excitatory actions of 5-HT and noradrenaline on pyramidal neurons of the mPFC $[128,135]$. Moreover, the fact that $5-\mathrm{HT}_{2 \mathrm{~A}}$ and $\alpha_{1}$-adrenoceptors are localized to the same cortical areas [136-138] provides a neuroanatomical support for the parallel action of $5-\mathrm{HT}_{2 \mathrm{~A}}$ and $\alpha_{1}$-adrenoceptor antagonists. The main difference in the cortical laminar distribution between $5-\mathrm{HT}_{2 \mathrm{~A}}$ and $\alpha_{1}$ adrenergic receptors is that the latter are separated in two bands around layer $\mathrm{V}$ $[139,140]$. In line with the present work, previous studies carried out in our laboratory have revealed that the perfusion of prazosin in the MPFC prevented the increase of 5-HT elicited by the cortical application of cirazoline, DOI and SAMPA [60], as well as thalamic disinhibition [60]. Because all these compounds do not interact directly with each other's receptors their effects need to be interpreted not at receptorial level, but at cellular (pyramidal) level. This is correspondence with the role of pyramidal cells of the mPFC in integrating multiple inputs from cortical as well as subcortical areas [141-143].

\section{IMPLICATIONS FOR ANTIPSYCHOTIC ACTION}

The findings of the present and previous [18, 62] work from our laboratory suggest that excessive glutamate transmission in the mPFC (resulting from NMDA receptor blockade) may be associated with some positive symptoms of schizophrenia, inasmuch as they are better treated by drugs that possess some degree of dopamine D2 receptor antagonism (a characteristic of the great majority of marketed antipsychotic drugs). In contrast, impairment of serotonergic pathways in the mPFC might rather be related to negative symptoms and/or cognitive deficits, conditions for which atypical antipsychotic drugs (e.g. clozapine and olanzapine) seem to display superior therapeutic efficacy. However, several recent studies have somehow challenged this purported higher efficacy in the clinic. Thus, the Clinical Antipsychotic Trials of Intervention Effectiveness (CATIE) study has shown that the typical drug 
perphenazine is as effective as other atypical drugs in terms of PANSS scores. However, olanzapine was the medication that patients stayed on the longest in the trial [144]. In similar terms, the Cost Utility of the Latest Antipsychotics in Severe Schizophrenia (CUtLASS) study also concluded that second-generation (atypical) antipsychotics do not offer significant clinical benefits over firstgeneration (typical) drugs when prescribed to patients with schizophrenia [145]. Altogether these studies illustrate the difficulty of translating from experimentally-observable pharmacological differences in the preclinical setting to therapeutic advantages.

Thus, there is a clear need for targeting different transmitter receptors in order to achieve better treatment (as well as a lower side-effect profile) of schizophrenia. Pharmacological models of schizophrenia based on NMDA antagonism, dopaminergic stimulants or serotonergic agonists point to an exacerbated glutamatergic transmission, at least in the mPFC. Our results suggest that, antagonism at $5-\mathrm{HT}_{2 \mathrm{~A}}$ and $\alpha_{1}$-adrenergic receptors, as well as agonism at $5-\mathrm{HT}_{1 \mathrm{~A}}$ receptors, are able to prevent the excessive glutamatergic transmission in the mPFC produced by such different conditions. In line with these results, it has been shown that $5-\mathrm{HT}$ and selective receptor agonists modulate the excitability of cortical neurons and their discharge rate through the activation of several receptor subtypes: namely $5-\mathrm{HT}_{1 \mathrm{~A}}, 5-\mathrm{HT}_{1 \mathrm{~B}}, 5-\mathrm{HT}_{2 \mathrm{~A} / 2 \mathrm{C}}$ and $5-\mathrm{HT}_{3}\left[128\right.$, 146-152]. Atypical antipsychotic drugs that exhibit 5- $\mathrm{HT}_{2 \mathrm{~A}}$ antagonism and/or $5-\mathrm{HT}_{1 \mathrm{~A}}$ agonism, such as clozapine, increase dopamine efflux in the mPFC of rodents [57, 153-157], which is potentially involved in the improvement of negative symptoms and cognitive dysfunction in schizophrenia $[154,155,158,159]$. This effect appears to be dependent on the presence of intact 5- $\mathrm{HT}_{1 \mathrm{~A}}$ receptors $[57,157]$. Given that some of these drugs (e.g. olanzapine) do not depict affinity for $5-\mathrm{HT}_{1 \mathrm{~A}}$ receptors (Table 1 ), it would seem that the $5-\mathrm{HT}_{1 \mathrm{~A}}$ receptor has a permissive role in this action, rather than being directly responsible. However, the increase in dopamine efflux produced by atypical antipsychotic drugs, including olanzapine, is inhibited by the $5-\mathrm{HT}_{1 \mathrm{~A}}$ receptor antagonist WAY 100635 [155] and absent in 5- $\mathrm{HT}_{1 \mathrm{~A}}$ receptor knockout mice [57], which suggests a pivotal role for $5-\mathrm{HT}_{1 \mathrm{~A}}$ agonism in some of the key 
properties desired for novel antipsychotic drugs. This concept is supported by clinical trials with partial $5-\mathrm{HT}_{1 \mathrm{~A}}$ receptor agonists, which report the ability of these compounds not only to reduce the incidence of EPS [46] but also to enhance some domains of cognitive function [47]. However, inconsistent results have been found depending on the antipsychotic drug and the $5-\mathrm{HT}_{1 \mathrm{~A}}$ receptor agonist used (reviewed in [160]).

With regard to $\alpha_{1}$-adrenoceptors, preclinical studies have revealed that the blockade of $\alpha_{1}$-adrenoceptors by prazosin potentiated the antipsychotic-like effect of dopamine D2 receptor antagonists [161]. In addition, all antipsychotic drugs used in this study display high in vitro affinity for $\alpha_{1}$-adrenoceptors (Table 1), which suggests a potential antipsychotic role of $\alpha_{1}$-adrenoceptor antagonism in the pharmacotherapy of schizophrenia. However, the use of drugs that possess a high $\alpha_{1}$-adrenoceptor antagonism in vivo is limited because their cardiovascular side-effects (hypotension, arrhythmia).

In summary, the intra-mPFC administration of M100907, repinotan and prazosin prevents MK-801-induced increase in 5-HT and glutamate, effects that are comparable to those obtained with clozapine and olanzapine [62; present study], and can be associated to a direct reduction the excitability of a subpopulation of pyramidal neurons in the MPFC (Fig (8)). Thus, it is possible that $5-\mathrm{HT}_{2 \mathrm{~A}}$ and $\alpha_{1}$-adrenergic receptor antagonism, as well as $5-\mathrm{HT} \mathrm{T}_{1 \mathrm{~A}}$ receptor agonism, may relate to a better treatment of most symptoms of schizophrenia. In fact, preclinical studies have shown that $5-\mathrm{HT}_{2 \mathrm{~A}}$ antagonists and $5-\mathrm{HT}_{1 \mathrm{~A}}$ agonists can alleviate cognitive deficits induced by NMDA receptor antagonists [61]. Because each of these receptor components do not confer antipsychotic properties individually, it is conceivable that a combined effect is necessary to achieve this goal.

In a recent work, Homayoun and Moghaddam demonstrated that clozapine has the unique feature of increasing the activity of putative pyramidal neurons with low baseline firing rates and decreasing the activity of neurons with higher firing rates in prefrontal cortex [64]. Given that antagonists at $D_{2} / D_{3}$, $\mathrm{D}_{4}, 5-\mathrm{HT}_{2 \mathrm{~A}}$ receptors and a dopamine D1 receptor antagonist are all able to 
increase basal extracellular glutamate on their own (Table 2), but they prevent the increase of glutamate release evoked by MK-801, the dual effect of clozapine can result from its interaction with such monoamine receptors, and this might be related to the pro-cognitive effects of the drug. It would be interesting to examine whether this effect of clozapine is shared by other atypical antipsychotic drugs with a similar pharmacological profile.

Unlike serotonergic and adrenergic compounds, the effects of dopaminergic compounds have been attributed to an increase in cortical inhibition responsible for a reduction of an excessive glutamatergic stimulation following NMDA antagonism ([62]; present study). This implies the localization of dopamine $D_{1} / D_{5}, D_{2} / D_{3}$ and $D_{4}$ receptors in a subpopulation of GABA interneurons (possibly those containing PV). Interestingly, the finding that a high concentration of the SKF 38393 is also able to prevent the MK-801-induced increase of cortical $5-H T$ seems to suggest that $D_{1} / D_{5}$ receptors are also located in a different set of GABA interneurons, perhaps those containing cholecystokinin $[162,163]$. Clozapine has been shown to enhance dopamine D1 receptor-mediated neurotransmission $[72,164]$. Therefore, the pro-cognitive action of clozapine could also result from its action on dopamine D1 receptors. Alternatively, it has also been suggested that the action of clozapine could involve potentiation of NMDA transmission (see [165] for review). Our results support a similar view for olanzapine. On the other hand, blockade of dopamine $D_{2} / D_{3}$ receptors may be in the front line of the pharmacological treatment of schizophrenia because dopamine $D_{2} / D_{3}$ antagonists would increase GABA inhibition directly, thus restoring cortical synchrony.

The conclusions raised in previous [62] and the present study are established as a result of the analogies present in the action of antipsychotic drugs and selective agonists and antagonists for monoaminergic receptors. However, it remains to be determined if different effects may emerge from a combination of multiple interactions among these receptors. Furthermore, as a general rule for psychiatric illnesses, caution must be taken in extrapolating the results obtained in an animal model to a clinical setting. 


\section{FUTURE TRENDS}

From the beginning of pharmacotherapy of schizophrenia, medicine cases have been filled with drugs that shared the characteristic of being dopamine D2 receptor antagonists. First generation typical antipsychotics like haloperidol and chlorpromazine potently block dopamine $D_{2} / D_{3} / D_{4}$ and $\alpha_{1}$-adrenergic receptors. The blockade of dopamine D2 receptors in the PFC and the nucleus accumbens appears to be beneficial for psychotic symptoms (delusions, hallucinations). However, the same action in other areas of the brain can cause severe EPS and hyperprolactinemia [33]. Second generation atypical antipsychotic drugs like clozapine and olanzapine keep some degree of dopamine $D_{2} / D_{3} / D_{4}$ antagonism, but they display a higher antagonism at 5 $\mathrm{HT}_{2 \mathrm{~A} / 2 \mathrm{C}}$ receptors. These features seem to be more effective for negative symptoms and cognitive deficits although some side-effects (weight gain, impairment of glucose and lipid metabolism) may appear [166]. However, this group of drugs is not homogeneous, and a recent meta-analysis of randomized controlled trials has shown that only four of these second-generation drugs (amisulpride, clozapine, olanzapine and risperidone) were better than firstgeneration antipsychotic drugs for overall efficacy [167]. The other secondgeneration drugs (quetiapine, sertindole, ziprasidone, zotepine) were not more efficacious than the first-generation drugs, even for negative symptoms. Therefore, efficacy on negative symptoms does not seem to be a core component of atypicality. Third generation antipsychotic drugs like aripiprazole and bifeprunox improve both positive and negative symptoms of schizophrenia without producing EPS or increases in serum prolactin [168, 169]. The unifying features of this third generation antipsychotics are the association of $D_{2} / D_{3}$ interaction (antagonism or partial agonism) with $5-\mathrm{HT}_{1 \mathrm{~A}}$ receptor activation without the requirement for $5-\mathrm{HT}_{2 \mathrm{~A}}$ receptor blockade. More recently it has been shown that drugs that interact with mGluR also have potential for the treatment of schizophrenia [37, 170,171]. However, a significant proportion of patients still do not experience complete remission of their positive symptoms and negative/cognitive symptoms remain poorly treated. In recent years, research 
and development efforts have sought novel "atypical" antipsychotic drugs that would offer the therapeutic advantages of clozapine without the associated risk of side effects.

In the search for reliable biomarkers to be used in R+D of newer drugs, our results first suggest that the blockade of an exacerbated 5-HT release in the mPFC induced by NMDA antagonists can be a useful biochemical marker of "atypicality" of antipsychotic drugs. Although this has been established for clozapine and olanzapine (drugs that display a similar pharmacological profile), further research is needed to determine whether this is a distinct feature of other second generation antipsychotic drugs and, most interestingly, if this holds also true for third generation antipsychotics (which represents receptor mechanisms that include dopamine $D_{2} / D_{3}$ receptor partial agonism).

GABAergic interneurons in prefrontal cortex play a critical role in cortical circuits by providing feedforward and feedback inhibition and synchronizing neuronal activity $[172,173]$. In this regard, we also propose that blockade of dopamine $D_{2} / D_{3} / D_{4}$ as well as dopamine $D_{1}$ agonism in the $M P F C$ may lead to a restoration of cortical GABA inhibition and synchrony alleged to be impaired in schizophrenia [102-104, 174]. Further support for this hypothesis has been obtained recently in our lab showing that both clozapine and haloperidol have the ability of reverse the effects of PCP on pyramidal cell firing and cortical synchronization [65]. However, it is also possible that the same effect is caused by different mechanisms, i.e. blockade of dopamine $D_{2} / D_{3} / D_{4}$ receptors (haloperidol) or $5-\mathrm{HT}_{2 \mathrm{~A}}$ receptors (clozapine). Further research is needed to verify such different alternatives.

On the other hand, antagonism at $5-\mathrm{HT}_{2 \mathrm{~A}}$ and $\alpha_{1}$-adrenergic receptors, as well as agonism at $5-\mathrm{HT}_{1 \mathrm{~A}}$ receptors may also be helpful by suppressing an excessive stimulation of pyramidal cells. One of the most important issues in this field is the fact that all these monoamine receptors implicated in the pharmacological treatment of schizophrenia are present in both pyramidal cells and GABA interneurons in the mPFC $[93,127]$. Therefore, the question arises as to what factors determine the binding of a drug predominantly to one of these 
cellular populations. With this in mind, newer antipsychotics would target receptors responsible for stimulating cortical GABA inhibition and diminishing excessive excitability of pyramidal cells without the undesired effects of similar actions in other areas of the brain. In addition, the regulatory changes of the complex formed by $5-\mathrm{HT}_{2 \mathrm{~A}}$ and mGluR2 receptors presumed to be involved in the altered cortical processes [175] also suggests that this receptor complex is a promising new target for the treatment of psychosis.

\section{ACKNOWLEDGEMENTS}

This work was supported by the Spanish Ministry of Health (FIS Grant PI070111 to A.A.), the Spanish Ministry of Education and Science (Grant SAF 2007-62378 to F.A.), and the Generalitat de Catalunya (SGR2005/00758). X.L.G. is the recipient of a predoctoral fellowship from the Consejo Superior de Investigaciones Científicas (CSIC). We gratefully acknowledge the skilful technical assistance of Leticia Campa and Verónica Paz. Thanks are also given to Bayer, Lundbeck and Pierre-Fabre for the generous supply of repinotan, citalopram and M100907, respectively. 


\section{REFERENCES}

[1] Javitt DC, Zukin SR. Recent advances in the phencyclidine model of schizophrenia. Am J Psychiatry 1991; 148: 1301-1308.

[2] Krystal JH, Karper LP, Seibyl JP, Freeman GK, Delaney R, Bremner JD, Heninger GR, Bowers MB, Jr., Charney DS. Subanesthetic effects of the noncompetitive NMDA antagonist, ketamine, in humans. Psychotomimetic, perceptual, cognitive, and neuroendocrine responses. Arch Gen Psychiatry 1994; 51: 199-214.

[3] Tamminga CA. Schizophrenia and glutamatergic transmission. Crit Rev Neurobiol 1998; 12: 21-36.

[4] Lahti AC, Koffel B, LaPorte D, Tamminga CA. Subanesthetic doses of ketamine stimulate psychosis in schizophrenia. Neuropsychopharmacology 1995; 13: 9-19.

[5] Lahti AC, Weiler MA, Tamara Michaelidis BA, Parwani A, Tamminga CA. Effects of ketamine in normal and schizophrenic volunteers. Neuropsychopharmacology 2001; 25: 455-467.

[6] Malhotra AK, Pinals DA, Weingartner H, Sirocco K, Missar CD, Pickar D, Breier A. NMDA receptor function and human cognition: the effects of ketamine in healthy volunteers. Neuropsychopharmacology 1996; 14: 301-307.

[7] Hertel P, Mathé JM, Nomikos GG, lurlo M, Mathé AA, Svensson TH. Effects of D-amphetamine and phencyclidine on behavior and extracellular concentrations of neurotensin and dopamine in the ventral striatum and the medial prefrontal cortex of the rat. Behav Brain Res 1995; 72: 103-114.

[8] Adams BW, Moghaddam B. Effect of clozapine, haloperidol, or M100907 on phencyclidine-activated glutamate efflux in the prefrontal cortex. Biol Psychiatry 2001; 50: 750-757.

[9] Homayoun H, Stefani MR, Adams BW, Tamagan GD, Moghaddam B. Functional interaction between NMDA and mGlu5 receptors: effects on working memory, instrumental learning, motor behaviors, and dopamine release. Neuropsychopharmacology 2004; 29: 1259-1269.

[10] Ellenbroek BA. Treatment of schizophrenia: a clinical and preclinical evaluation of neuroleptic drugs. Pharmacol Ther 1993; 57: 1-78.

[11] Moghaddam B, Adams BW. Reversal of phencyclidine effects by a group II metabotropic glutamate receptor agonist in rats. Science 1998; 281: 1349-1352.

[12] Jentsch JD, Roth RH. The neuropsychopharmacology of phencyclidine: from NMDA receptor hypofunction to the dopamine hypothesis of schizophrenia. Neuropsychopharmacology 1999; 20: 201-225.

[13] Mohn AR, Gainetdinov RR, Caron MG, Koller BH. Mice with reduced NMDA receptor expression display behaviors related to schizophrenia. Cell 1999; 98: 427-436.

[14] Moghaddam B, Adams B, Verma A, Daly D. Activation of glutamatergic neurotransmission by ketamine: a novel step in the pathway from NMDA receptor blockade to dopaminergic and cognitive disruptions associated with the prefrontal cortex. J Neurosci 1997; 17: 2921-2927. 
[15] Lorrain DS, Baccei CS, Bristow LJ, Anderson JJ, Varney MA. Effects of ketamine and $N$-methyl-D-aspartate on glutamate and dopamine release in the rat prefrontal cortex: modulation by a group II selective metabotropic glutamate receptor agonist LY379268. Neuroscience 2003; 117: 697-706.

[16] Ceglia I, Carli M, Baviera M, Renoldi G, Calcagno E, Invernizzi RW. The 5-HT receptor antagonist M100,907 prevents extracellular glutamate rising in response to NMDA receptor blockade in the mPFC. J Neurochem 2004; 91: 189-199.

[17] Calcagno E, Carli M, Invernizzi RW. The 5- $\mathrm{HT}_{1 \mathrm{~A}}$ receptor agonist 8-OHDPAT prevents prefrontocortical glutamate and serotonin release in response to blockade of cortical NMDA receptors. J Neurochem 2006; 96: 853-8.

[18] López-Gil X, Babot Z, Amargós-Bosch M, Suñol C, Artigas F, Adell A. Clozapine and haloperidol differently suppress the MK-801-increased glutamatergic and serotonergic transmission in the medial prefrontal cortex of the rat. Neuropsychopharmacology 2007; 32: 2087-2097.

[19] Schmidt CJ, Fadayel GM. Regional effects of MK-801 on dopamine release: effects of competitive NMDA or 5-HT2A receptor blockade. J Pharmacol Exp Ther 1996; 277: 1541-1549.

[20] Adams B, Moghaddam B. Corticolimbic dopamine neurotransmission is temporally dissociated from the cognitive and locomotor effects of phencyclidine. J Neurosci 1998; 18: 5545-5554.

[21] Millan MJ, Brocco M, Gobert A, Joly F, Bervoets K, Rivet J, NewmanTancredi A, Audinot V, Maurel S. Contrasting mechanisms of action and sensitivity to antipsychotics of phencyclidine versus amphetamine: importance of nucleus accumbens 5- $\mathrm{HT}_{2 \mathrm{~A}}$ sites for PCP-induced locomotion in the rat. Eur J Neurosci 1999; 11: 4419-4432.

[22] Amargós-Bosch M, López-Gil X, Artigas F, Adell A. Clozapine and olanzapine, but not haloperidol, suppress serotonin efflux in the medial prefrontal cortex elicited by phencyclidine and ketamine. Int $\mathrm{J}$ Neuropsychopharmacol 2006; 9: 565-573.

[23] Krystal JH, D'Souza DC, Mathalon D, Perry E, Belger A, Hoffman R. NMDA receptor antagonist effects, cortical glutamatergic function, and schizophrenia: toward a paradigm shift in medication development. Psychopharmacology 2003; 169: 215-233.

[24] Homayoun H, Moghaddam B. NMDA receptor hypofunction produces opposite effects on prefrontal cortex interneurons and pyramidal neurons. J Neurosci 2007; 27: 11496-11500.

[25] Grunze HC, Rainnie DG, Hasselmo ME, Barkai E, Hearn EF, McCarley RW, Greene RW. NMDA-dependent modulation of CA1 local circuit inhibition. J Neurosci 1996; 16: 2034-2043.

[26] Li Q, Clark S, Lewis DV, Wilson WA. NMDA receptor antagonists disinhibit rat posterior cingulate and retrosplenial cortices: a potential mechanism of neurotoxicity. J Neurosci 2002; 22: 3070-3080.

[27] Hajós M. Targeting information-processing deficit in schizophrenia: a novel approach to psychotherapeutic drug discovery. Trends Pharmacol Sci 2006; 27: 391-398. 
[28] Andreasen NC, Rezai K, Alliger R, Swayze VW, Flaum M, Kirchner P, Cohen G, O'Leary DS. Hypofrontality in neuroleptic-naive patients and in patients with chronic schizophrenia. Assessment with xenon 133 singlephoton emission computed tomography and the Tower of London. Arch Gen Psychiatry 1992; 49: 943-958.

[29] Siegel BV, Jr., Buchsbaum MS, Bunney WE, Jr., Gottschalk LA, Haier RJ, Lohr JB, Lottenberg S, Najafi A, Nuechterlein KH, Potkin SG. Cortical-striatal-thalamic circuits and brain glucose metabolic activity in 70 unmedicated male schizophrenic patients. Am J Psychiatry 1993; 150: 1325-1336.

[30] Gur RE, Mozley PD, Resnick SM, Mozley LH, Shtasel DL, Gallacher F, Arnold SE, Karp JS, Alavi A, Reivich M. Resting cerebral glucose metabolism in first-episode and previously treated patients with schizophrenia relates to clinical features. Arch Gen Psychiatry 1995; 52: 657-667.

[31] Norman RM, Malla AK, Morrison-Stewart SL, Helmes E, Williamson PC, Thomas J, Cortese L. Neuropsychological correlates of syndromes in schizophrenia. Br J Psychiatry 1997; 170: 134-139.

[32] Abi-Dargham A, Mawlawi O, Lombardo I, Gil R, Martinez D, Huang Y, Hwang DR, Keilp J, Kochan L, Van Heertum R, Gorman JM, Laruelle M. Prefrontal dopamine $D_{1}$ receptors and working memory in schizophrenia. J Neurosci 2002; 22: 3708-3719.

[33] Kapur S, Zipursky R, Jones C, Remington G, Houle S. Relationship between dopamine $D_{2}$ occupancy, clinical response, and side effects: a double-blind PET study of first-episode schizophrenia. Am J Psychiatry 2000; 157: 514-520.

[34] Seeman P, Lee T, Chau-Wong M, Wong K. Antipsychotic drug doses and neuroleptic/dopamine receptors. Nature 1976; 261: 717-719.

[35] Creese I, Burt DR, Snyder SH. Dopamine receptor binding predicts clinical and pharmacological potencies of antischizophrenic drugs. J Neuropsychiatry Clin Neurosci 1996; 8: 223-226.

[36] Kapur S, Mamo D. Half a century of antipsychotics and still a central role for dopamine D2 receptors. Prog Neuropsychopharmacol Biol Psychiatry 2003; 27: 1081-1090.

[37] Patil ST, Zhang L, Martenyi F, Lowe SL, Jackson KA, Andreev BV, Avedisova AS, Bardenstein LM, Gurovich IY, Morozova MA, Mosolov SN, Neznanov NG, Reznik AM, Smulevich AB, Tochilov VA, Johnson BG, Monn JA, Schoepp DD. Activation of mGlu2/3 receptors as a new approach to treat schizophrenia: a randomized Phase 2 clinical trial. Nat Med 2007; 13: 1102-1107.

[38] Kapur S, Seeman P. Does fast dissociation from the dopamine $D_{2}$ receptor explain the action of atypical antipsychotics?: A new hypothesis. Am J Psychiatry 2001; 158: 360-369.

[39] Meltzer HY. What's atypical about atypical antipsychotic drugs? Curr Opin Pharmacol 2004; 4: 53-57.

[40] Kapur S, Zipursky RB, Remington G. Clinical and theoretical implications of 5-HT2 and D2 receptor occupancy of clozapine, risperidone, and olanzapine in schizophrenia. Am J Psychiatry 1999; 156: 286-293. 
[41] Abi-Dargham $A$, Moore $H$. Prefrontal DA transmission at $D_{1}$ receptors and the pathology of schizophrenia. Neuroscientist 2003; 9: 404-416.

[42] Goldman-Rakic PS, Castner SA, Svensson TH, Siever LJ, Williams GV. Targeting the dopamine $D_{1}$ receptor in schizophrenia: insights for cognitive dysfunction. Psychopharmacology 2004; 174: 3-16.

[43] Okubo Y, Suhara T, Suzuki K, Kobayashi K, Inoue O, Terasaki O, Someya Y, Sassa T, Sudo Y, Matsushima E, lyo M, Tateno Y, Toru M. Decreased prefrontal dopamine D1 receptors in schizophrenia revealed by PET. Nature 1997; 385: 634-636.

[44] Bymaster FP, Calligaro DO, Falcone JF, Marsh RD, Moore NA, Tye NC, Seeman P, Wong DT. Radioreceptor binding profile of the atypical antipsychotic olanzapine. Neuropsychopharmacology 1996; 14: 87-96.

[45] Schotte A, Janssen PF, Gommeren W, Luyten WH, Van Gompel P, Lesage, AS, De Loore K, Leysen, JE. Risperidone compared with new and reference antipsychotic drugs: in vitro and in vivo receptor binding. Psychopharmacology 1996; 124: 57-73.

[46] Millan MJ. Improving the treatment of schizophrenia: focus on serotonin (5-HT) $)_{1 \mathrm{~A}}$ receptors. J Pharmacol Exp Ther 2000; 295: 853-861.

[47] Sumiyoshi T, Matsui M, Yamashita I, Nohara S, Kurachi M, Uehara T, Sumiyoshi S, Sumiyoshi C, Meltzer HY. The effect of tandospirone, a serotonin(1A) agonist, on memory function in schizophrenia. Biol Psychiatry 2001; 49: 861-868.

[48] McCreary AC, Glennon JC, Ashby CR, Jr., Meltzer HY, Li Z, Reinders $\mathrm{JH}$, Hesselink MB, Long SK, Herremans $A H$, van Stuivenberg $H$, Feenstra RW, Kruse CG. SLV313 (1-(2,3-dihydro-benzo[1,4]dioxin-5-yl)4-[5-(4-fluoro-phenyl)-pyridin-3-ylmethyl]-piperazine monohydrochloride): a novel dopamine $\mathrm{D} 2$ receptor antagonist and $5-\mathrm{HT}_{1 \mathrm{~A}}$ receptor agonist potential antipsychotic drug. Neuropsychopharmacology 2007; 32: 78-94.

[49] Jones CA, McCreary AC. Serotonergic approaches in the development of novel antipsychotics. Neuropharmacology 2008; 55: 1056-1065.

[50] Goff DC, Midha KK, Brotman AW, McCormick S, Waites M, Amico ET. An open trial of buspirone added to neuroleptics in schizophrenic patients. J Clin Psychopharmacol 1991; 11: 193-197.

[51] Moss LE, Neppe VM, Drevets WC. Buspirone in the treatment of tardive dyskinesia. J Clin Psychopharmacol 1993; 13: 204-209.

[52] Arnt J, Skarsfeldt T. Do novel antipsychotics have similar pharmacological characteristics? A review of the evidence. Neuropsychopharmacology 1998; 18: 63-101.

[53] Svensson TH. Alpha-adrenoceptor modulation hypothesis of antipsychotic atypicality. Prog Neuropsychopharmacol Biol Psychiatry 2003; 27: 1145-1158.

[54] Alsene KM, Carasso BS, Connors EE, Bakshi VP. Disruption of prepulse inhibition after stimulation of central but not peripheral $\alpha-1$ adrenergic receptors. Neuropsychopharmacology 2006; 31: 2150-2161.

[55] Geyer MA, Krebs-Thomson K, Braff DL, Swerdlow NR. Pharmacological studies of prepulse inhibition models of sensorimotor gating deficits in schizophrenia: a decade in review. Psychopharmacology 2001; 156: 117154. 
[56] Li XM, Perry KW, Wong DT, Bymaster FP. Olanzapine increases in vivo dopamine and norepinephrine release in rat prefrontal cortex, nucleus accumbens and striatum. Psychopharmacology 1998; 136: 153-161.

[57] Díaz-Mataix L, Scorza MC, Bortolozzi A, Toth M, Celada P, Artigas F. Involvement of $5-\mathrm{HT}_{1 \mathrm{~A}}$ receptors in prefrontal cortex in the modulation of dopaminergic activity: role in atypical antipsychotic action. J Neurosci 2005; 25: 10831-10843.

[58] Duncan GE, Leipzig JN, Mailman RB, Lieberman JA. Differential effects of clozapine and haloperidol on ketamine-induced brain metabolic activation. Brain Res 1998; 812: 65-75.

[59] Amargós-Bosch M, Adell A, Bortolozzi A, Artigas F. Stimulation of $\alpha_{1}$ adrenoceptors in the rat medial prefrontal cortex increases the local in vivo 5-hydroxytryptamine release: reversal by antipsychotic drugs. J Neurochem 2003; 87: 831-842.

[60] Amargós-Bosch M, Adell A, Artigas F. Antipsychotic drugs reverse the AMPA receptor-stimulated release of $5-\mathrm{HT}$ in the medial prefrontal cortex. J Neurochem 2007; 102: 550-561.

[61] Carli M, Baviera M, Invernizzi RW, Balducci C. Dissociable contribution of $5-\mathrm{HT}_{1 \mathrm{~A}}$ and $5-\mathrm{HT}_{2 \mathrm{~A}}$ receptors in the medial prefrontal cortex to different aspects of executive control such as impulsivity and compulsive perseveration in rats. Neuropsychopharmacology 2006; 31: 757-7.

[62] López-Gil X, Artigas F, Adell A. Role of different monoamine receptors controlling MK-801-induced release of serotonin and glutamate in the medial prefrontal cortex: relevance for antipsychotic action. Int $\mathrm{J}$ Neuropsychopharmacol 2009; 12: 487-499.

[63] Abekawa T, Ito K, Koyama T. Role of the simultaneous enhancement of NMDA and dopamine $D_{1}$ receptor-mediated neurotransmission in the effects of clozapine on phencyclidine-induced acute increases in glutamate levels in the rat medial prefrontal cortex. Naunyn Schmiedebergs Arch Pharmacol 2006; 374: 177-193.

[64] Homayoun H, Moghaddam B. Fine-tuning of awake prefrontal cortex neurons by clozapine: comparison with haloperidol and $\mathrm{N}$ desmethylclozapine. Biol Psychiatry 2007; 61: 679-687.

[65] Kargieman L, Santana N, Mengod G, Celada P, Artigas F. Antipsychotic drugs reverse the disruption in prefrontal cortex function produced by NMDA receptor blockade with phencyclidine. Proc Natl Acad Sci USA 2007; 104: 14843-14848.

[66] Fuster JM. The prefrontal cortex-an update: time is of the essence. Neuron 2001; 30: 319-333.

[67] Lewis DA, Lieberman JA. Catching up on schizophrenia: natural history and neurobiology. Neuron 2000; 28: 325-334.

[68] Celada P, Castañé A, Adell A, Artigas F. Modeling schizophrenia in experimental animals. In: Buschmann H, Díaz JL, Holenz J, Párraga A, Torrens A, Vela JM (Eds) Antidepressants, Antipsychotics, Anxiolytics. From Chemistry and Pharmacology to Clinical Application, Vol 1. Weinheim, Wiley-VCH. 2007; 449-489.

[69] Hervás I, Queiroz CM, Adell A, Artigas F. Role of uptake inhibition and autoreceptor activation in the control of 5-HT release in the frontal cortex and dorsal hippocampus of the rat. $\mathrm{Br} \mathrm{J}$ Pharmacol 2000; 130: 160-166. 
[70] West AR, Grace AA. Opposite influences of endogenous dopamine D1 and D2 receptor activation on activity states and electrophysiological properties of striatal neurons: studies combining in vivo intracellular recordings and reverse microdialysis. J Neurosci 2002; 22: 294-304.

[71] Martín-Ruiz R, Puig MV, Celada P, Shapiro DA, Roth BL, Mengod G, Artigas $\mathrm{F}$. Control of serotonergic function in medial prefrontal cortex by serotonin-2A receptors through a glutamate-dependent mechanism. J Neurosci 2001; 21: 9856-9866.

[72] Oerther S, Ahlenius S. Atypical antipsychotics and dopamine $D_{1}$ receptor agonism: an in vivo experimental study using core temperature measurements in the rat. J Pharmacol Exp Ther 2000; 292: 731-736.

[73] Roth BL, Sheffler D, Potkin SG. Atypical antipsychotic drug actions: unitary or multiple mechanisms for "atypicality"? Clin Neurosci Res 2003; 3: 108-117.

[74] Hertel P, Nomikos GG, Schilström B, Arborelius L, Svensson TH. Risperidone dose-dependently increases extracellular concentrations of serotonin in the rat frontal cortex: Role of $\alpha_{2}$-adrenoceptor antagonism. Neuropsychopharmacology 1997; 17: 44-55.

[75] Ichikawa J, Kuroki T, Dai J, Meltzer HY. Effect of antipsychotic drugs on extracellular serotonin levels in rat medial prefrontal cortex and nucleus accumbens. Eur J Pharmacol 1998; 351: 163-171.

[76] Hertel P, Fagerquist MV, Svensson TH. Enhanced cortical dopamine output and antipsychotic-like effects of raclopride by $\alpha_{2}$ adrenoceptor blockade. Science 1999; 286: 105-107.

[77] Suzuki Y, Jodo E, Takeuchi S, Niwa S, Kayama Y. Acute administration of phencyclidine induces tonic activation of medial prefrontal cortex neurons in freely moving rats. Neuroscience 2002; 114: 769-779.

[78] Jackson ME, Homayoun $\mathrm{H}$, Moghaddam B. NMDA receptor hypofunction produces concomitant firing rate potentiation and burst activity reduction in the prefrontal cortex. Proc Natl Acad Sci USA 2004; 101: 8467-8472.

[79] Katayama T, Jodo E, Suzuki Y, Hoshino KY, Takeuchi S, Kayama Y. Activation of medial prefrontal cortex neurons by phencyclidine is mediated via AMPA/kainate glutamate receptors in anesthetized rats. Neuroscience 2007; 150: 442-448.

[80] Takahata R, Moghaddam B. Activation of glutamate neurotransmission in the prefrontal cortex sustains the motoric and dopaminergic effects of phencyclidine. Neuropsychopharmacology 2003; 28: 1117-1124.

[81] Seeger TF, Seymour PA, Schmidt AW, Zorn SH, Schulz DW, Lebel LA, McLean S, Guanowsky V, Howard HR, Lowe JA, III. Ziprasidone (CP88,059): a new antipsychotic with combined dopamine and serotonin receptor antagonist activity. J Pharmacol Exp Ther 1995; 275: 101-113.

[82] Roth BL, Tandra S, Burgess LH, Sibley DR, Meltzer HY. D4 dopamine receptor binding affinity does not distinguish between typical and atypical antipsychotic drugs. Psychopharmacology 1995; 120: 365-368.

[83] Lawler CP, Prioleau C, Lewis MM, Mak C, Jiang D, Schetz JA, Gonzalez AM, Sibley DR, Mailman RB. Interactions of the novel antipsychotic aripiprazole (OPC-14597) with dopamine and serotonin receptor subtypes. Neuropsychopharmacology 1999; 20: 612-627. 
[84] Gabbott PL, Warner TA, Jays PR, Salway P, Busby SJ. Prefrontal cortex in the rat: projections to subcortical autonomic, motor, and limbic centers. J Comp Neurol 2005; 492: 145-177.

[85] Strange PG. Antipsychotic drugs: importance of dopamine receptors for mechanisms of therapeutic actions and side effects. Pharmacol Rev 2001; 53: 119-133.

[86] Tang L, Todd RD, Heller A, O'Malley KL. Pharmacological and functional characterization of $D_{2}, D_{3}$ and $D_{4}$ dopamine receptors in fibroblast and dopaminergic cell lines. J Pharmacol Exp Ther 1994; 268: 495-502.

[87] Assié MB, Dominguez H, Consul-Denjean N, Newman-Tancredi A. In vivo occupancy of dopamine D2 receptors by antipsychotic drugs and novel compounds in the mouse striatum and olfactory tubercles. Naunyn Schmiedebergs Arch Pharmacol 2006; 373: 441-450.

[88] Mathé JM, Nomikos GG, Blakeman KH, Svensson TH. Differential actions of dizocilpine (MK-801) on the mesolimbic and mesocortical dopamine systems: role of neuronal activity. Neuropharmacology 1999; 38: 121-128.

[89] Wang Y, Goldman-Rakic PS. D2 receptor regulation of synaptic burst firing in prefrontal cortical pyramidal neurons. Proc Natl Acad Sci USA 2004; 101: 5093-5.

[90] Vincent SL, Khan Y, Benes FM. Cellular colocalization of dopamine D1 and D2 receptors in rat medial prefrontal cortex. Synapse 1995; 19: 112120.

[91] Khan ZU, Gutiérrez A, Martin R, Peñafiel A, Rivera A, De La Calle A. Differential regional and cellular distribution of dopamine D2-like receptors: an immunocytochemical study of subtype-specific antibodies in rat and human brain. J Comp Neurol 1998; 402: 353-371.

[92] Le Moine C, Gaspar P. Subpopulations of cortical GABAergic interneurons differ by their expression of $D_{1}$ and $D_{2}$ dopamine receptor subtypes. Brain Res Mol Brain Res 1998; 58: 231-236.

[93] Santana N, Mengod G, Artigas F. Quantitative Analysis of the Expression of Dopamine $D_{1}$ and $D_{2}$ Receptors in Pyramidal and GABAergic Neurons of the Rat Prefrontal Cortex. Cereb Cortex 2008; Published online by Oxford University Press, 9 Aug 2008; doi:10.1093/cercor/bhn134.

[94] Benes FM, Taylor JB, Cunningham MC. Convergence and plasticity of monoaminergic systems in the medial prefrontal cortex during the postnatal period: implications for the development of psychopathology. Cereb Cortex 2000; 10: 1014-1027.

[95] Sesack SR, Hawrylak VA, Melchitzky DS, Lewis DA. Dopamine innervation of a subclass of local circuit neurons in monkey prefrontal cortex: ultrastructural analysis of tyrosine hydroxylase and parvalbumin immunoreactive structures. Cereb Cortex 1998; 8: 614-622.

[96] Gorelova N, Seamans JK, Yang CR. Mechanisms of dopamine activation of fast-spiking interneurons that exert inhibition in rat prefrontal cortex. J Neurophysiol 2002; 88: 3150-3166.

[97] Benes FM, Berretta S. GABAergic interneurons: implications for understanding schizophrenia and bipolar disorder. Neuropsychopharmacology 2001; 25: 1-27. 
[98] De Felipe J. Cortical interneurons: from Cajal to 2001. Prog Brain Res 2002; 136: 215-238.

[99] Seamans JK, Gorelova N, Durstewitz D, Yang CR. Bidirectional dopamine modulation of GABAergic inhibition in prefrontal cortical pyramidal neurons. J Neurosci 2001; 21: 3628-3638.

[100] Gao WJ, Wang Y, Goldman-Rakic PS. Dopamine modulation of perisomatic and peridendritic inhibition in prefrontal cortex. J Neurosci 2003; 23: 1622-1630.

[101] Benes FM. Model generation and testing to probe neural circuitry in the cingulate cortex of postmortem schizophrenic brain. Schizophr Bull 1998; 24: 219-230.

[102] Beasley CL, Zhang ZJ, Patten I, Reynolds GP. Selective deficits in prefrontal cortical GABAergic neurons in schizophrenia defined by the presence of calcium-binding proteins. Biol Psychiatry 2002; 52: 708-715.

[103] Benes FM. The role of stress and dopamine-GABA interactions in the vulnerability for schizophrenia. J Psychiatr Res 1997; 31: 257-275.

[104] Egan MF, Weinberger DR. Neurobiology of schizophrenia. Curr Opin Neurobiol 1997; 7: 701-707.

[105] Markram H, Toledo-Rodriguez M, Wang Y, Gupta A, Silberberg G, Wu C. Interneurons of the neocortical inhibitory system. Nat Rev Neurosci 2004; 5: 793-807.

[106] Hájos N, Pálhalmi J, Mann EO, Németh B, Paulsen O, Freund TF. Spike timing of distinct types of GABAergic interneuron during hippocampal gamma oscillations in vitro. J Neurosci 2004; 24: 9127-9137.

[107] Tukker JJ, Fuentealba P, Hartwich K, Somogyi P, Klausberger T. Cell type-specific tuning of hippocampal interneuron firing during gamma oscillations in vivo. J Neurosci 2007; 27: 8184-8189.

[108] Gonzalez-Burgos G, Lewis DA. GABA neurons and the mechanisms of network oscillations: implications for understanding cortical dysfunction in schizophrenia. Schizophr Bull 2008; 34: 944-961.

[109] Lahti RA, Roberts RC, Conley RR, Cochrane EV, Mutin A, Tamminga CA. D2-type dopamine receptors in postmortem human brain sections from normal and schizophrenic subjects. Neuroreport 1996; 7: 19451948.

[110] Mrzljak L, Bergson C, Pappy M, Huff R, Levenson R, Goldman-Rakic PS. Localization of dopamine D4 receptors in GABAergic neurons of the primate brain. Nature 1996; 381: 245-248.

[111] Defagot MC, Antonelli MC. Autoradiographic localization of the putative D4 dopamine receptor in rat brain. Neurochem Res 1997; 22: 401-407.

[112] Defagot MC, Malchiodi EL, Villar MJ, Antonelli MC. Distribution of D4 dopamine receptor in rat brain with sequence-specific antibodies. Brain Res Mol Brain Res 1997; 45: 1-12.

[113] Ariano MA, Wang J, Noblett KL, Larson ER, Sibley DR. Cellular distribution of the rat D4 dopamine receptor protein in the CNS using anti-receptor antisera. Brain Res 1997; 752: 26-34.

[114] Wedzony K, Chocyk A, Mackowiak M, Fijal K, Czyrak A. Cortical localization of dopamine $\mathrm{D}_{4}$ receptors in the rat brain-immunocytochemical study. J Physiol Pharmacol 2000; 51: 205-221. 
[115] Noaín D, Avale ME, Wedemeyer C, Calvo D, Peper M, Rubinstein M. Identification of brain neurons expressing the dopamine $D_{4}$ receptor gene using BAC transgenic mice. Eur J Neurosci 2006; 24: 2429-2438.

[116] Abi-Dargham A. Probing cortical dopamine function in schizophrenia: what can D1 receptors tell us? World Psychiatry 2003; 2: 166-171.

[117] Bubenikova-Valesova V, Svoboda J, Horacek J, Vales K. The effect of a full agonist/antagonist of the $D_{1}$ receptor on locomotor activity, sensorimotor gating and cognitive function in dizocilpine-treated rats. Int J Neuropsychopharmacol ; Published online by Cambridge University Press, 2009 Jan 20; doi:10.1017/S1461145708009851.

[118] Bergson C, Mrzljak L, Smiley JF, Pappy M, Levenson R, Goldman-Rakic PS. Regional, cellular, and subcellular variations in the distribution of $D_{1}$ and $D_{5}$ dopamine receptors in primate brain. J Neurosci 1995; 15: 78217836.

[119] Davidoff SA, Benes FM. High-resolution scatchard analysis shows D1 receptor binding on pyramidal and nonpyramidal neurons. Synapse 1998; 28: 83-90.

[120] Glausier JR, Khan ZU, Muly EC. Dopamine $D_{1}$ and $D_{5}$ Receptors Are Localized to Discrete Populations of Interneurons in Primate Prefrontal Cortex. Cereb Cortex 2008; Published online by Oxford University Press, November 19 2008; doi:10.1093/cercor/bhn212.

[121] Muly EC, III, Szigeti K, Goldman-Rakic PS. D 1 receptor in interneurons of macaque prefrontal cortex: distribution and subcellular localization. $J$ Neurosci 1998; 18: 10553-10565.

[122] Grace AA. Phasic versus tonic dopamine release and the modulation of dopamine system responsivity: a hypothesis for the etiology of schizophrenia. Neuroscience 1991; 41: 1-24.

[123] Kehne JH, Baron BM, Carr AA, Chaney SF, Elands J, Feldman DJ, Frank RA, van Giersbergen PL, McCloskey TC, Johnson MP, McCarty DR, Poirot M, Senyah Y, Siegel BW, Widmaier C. Preclinical characterization of the potential of the putative atypical antipsychotic MDL 100,907 as a potent 5- $\mathrm{HT}_{2 \mathrm{~A}}$ antagonist with a favorable CNS safety profile. J Pharmacol Exp Ther 1996; 277: 968-981.

[124] Amargós-Bosch M, Bortolozzi A, Puig MV, Serrats J, Adell A, Celada P, Toth M, Mengod G, Artigas F. Co-expression and in vivo interaction of serotonin $_{1 \mathrm{~A}}$ and serotonin $_{2 \mathrm{~A}}$ receptors in pyramidal neurons of prefrontal cortex. Cereb Cortex 2004; 14: 281-299.

[125] Willins DL, Deutch AY, Roth BL. Serotonin 5- $\mathrm{HT}_{2 A}$ receptors are expressed on pyramidal cells and interneurons in the rat cortex. Synapse 1997; 27: 79-82.

[126] Cornea-Hébert V, Riad M, Wu C, Singh SK, Descarries L. Cellular and subcellular distribution of the serotonin $5-\mathrm{HT}_{2 \mathrm{~A}}$ receptor in the central nervous system of adult rat. J Comp Neurol 1999; 409: 187-209.

[127] Santana N, Bortolozzi A, Serrats J, Mengod G, Artigas F. Expression of serotonin $_{1 A}$ and serotonin $_{2 A}$ receptors in pyramidal and GABAergic neurons of the rat prefrontal cortex. Cereb Cortex 2004; 14: 1100-1109.

[128] Araneda R, Andrade R. 5-Hydroxytryptamine ${ }_{2}$ and 5-hydroxytryptamine ${ }_{1 \mathrm{~A}}$ receptors mediate opposing responses on membrane excitability in rat association cortex. Neuroscience 1991; 40: 399-412. 
[129] Ashby CR, Jr., Edwards E, Wang RY. Electrophysiological evidence for a functional interaction between $5-\mathrm{HT}_{1 \mathrm{~A}}$ and $5-\mathrm{HT}_{2 \mathrm{~A}}$ receptors in the rat medial prefrontal cortex: an iontophoretic study. Synapse 1994; 17: 173181.

[130] Celada P, Puig MV, Casanovas JM, Guillazo G, Artigas F. Control of dorsal raphe serotonergic neurons by the medial prefrontal cortex: Involvement of serotonin-1A, GABA ${ }_{A}$, and glutamate receptors. J Neurosci 2001; 21: 9917-9929.

[131] De Vry J, Schohe-Loop R, Heine HG, Greuel JM, Mauler F, Schmidt B, Sommermeyer $\mathrm{H}$, Glaser T. Characterization of the aminomethylchroman derivative BAY $\times 3702$ as a highly potent 5-hydroxytryptamine1A receptor agonist. J Pharmacol Exp Ther 1998; 284: 1082-1094.

[132] Czyrak A, Czepiel K, Mackowiak M, Chocyk A, Wedzony K. Serotonin 5$\mathrm{HT}_{1 \mathrm{~A}}$ receptors might control the output of cortical glutamatergic neurons in rat cingulate cortex. Brain Res 2003; 989: 42-51.

[133] Aznar S, Qian Z, Shah R, Rahbek B, Knudsen GM. The 5-HT 1 A serotonin receptor is located on calbindin- and parvalbumin-containing neurons in the rat brain. Brain Res 2003; 959: 58-67.

[134] Schwinn DA, Johnston GI, Page SO, Mosley MJ, Wilson KH, Worman NP, Campbell S, Fidock MD, Furness LM, Parry-Smith DJ. Cloning and pharmacological characterization of human alpha-1 adrenergic receptors: sequence corrections and direct comparison with other species homologues. J Pharmacol Exp Ther 1995; 272: 134-142.

[135] Marek GJ, Aghajanian GK. 5- $\mathrm{HT}_{2 \mathrm{~A}}$ receptor or $\alpha_{1}$-adrenoceptor activation induces excitatory postsynaptic currents in layer $\mathrm{V}$ pyramidal cells of the medial prefrontal cortex. Eur J Pharmacol 1999; 367: 197-206.

[136] Day HE, Campeau S, Watson SJ, Jr., Akil H. Distribution of $\alpha_{1 a-}, \alpha_{1 b-}$ and $\alpha_{1 \mathrm{~d}}$-adrenergic receptor mRNA in the rat brain and spinal cord. $\mathrm{J}$ Chem Neuroanat 1997; 13: 115-139.

[137] Domyancic AV, Morilak DA. Distribution of $\alpha_{1 A}$ adrenergic receptor mRNA in the rat brain visualized by in situ hybridization. J Comp Neurol 1997; 386: 358-378.

[138] Pieribone VA, Nicholas AP, Dagerlind A, Hökfelt T. Distribution of $\alpha_{1}$ adrenoceptors in rat brain revealed by in situ hybridization experiments utilizing subtype-specific probes. J Neurosci 1994; 14: 4252-4268.

[139] Jones LS, Gauger LL, Davis JN. Anatomy of brain alpha ${ }_{1}$-adrenergic receptors: in vitro autoradiography with [ $\left.{ }^{125} \mathrm{I}\right]$-heat. J Comp Neurol 1985; 231: 190-208.

[140] Palacios JM, Hoyer D, Cortés R. $\alpha_{1}$-Adrenoceptors in the mammalian brain: similar pharmacology but different distribution in rodents and primates. Brain Res 1987; 419: 65-75.

[141] Kuroda M, Yokofujita J, Murakami K. An ultrastructural study of the neural circuit between the prefrontal cortex and the mediodorsal nucleus of the thalamus. Prog Neurobiol 1998; 54: 417-4.

[142] Groenewegen HJ, Uylings HBM. The prefrontal cortex and the integration of sensory, limbic and autonomic function. Progr Brain Res 2000; 126: 328. 
[143] Heidbreder CA, Groenewegen HJ. The medial prefrontal cortex in the rat: evidence for a dorso-ventral distinction based upon functional and anatomical characteristics. Neurosci Biobehav Rev 2003; 27: 555-579.

[144] Lieberman JA, Stroup TS, McEvoy JP, Swartz MS, Rosenheck RA, Perkins DO, Keefe RSE, Davis SM, Davis CE, Lebowitz BD, Severe J, Hsiao JK, Clinical Antipsychotic Trials of Intervention Effectiveness (CATIE) Investigators. Effectiveness of antipsychotic drugs in patients with chronic schizophrenia. N Engl J Med 2005; 353: 1209-1223.

[145] Jones PB, Barnes TRE, Davies L, Dunn G, Lloyd H, Hayhurst KP, Murray RM, Markwick A, Lewis SW. Randomized controlled trial of the effect on quality of life of second- vs first-generation antipsychotic drugs in schizophrenia: Cost Utility of the Latest Antipsychotic Drugs in Schizophrenia Study (CUtLASS 1). Arch Gen Psychiatry 2006; 63: 10791087.

[146] Ashby CR, Jr., Edwards E, Harkins K, Wang RY. Effects of ( \pm )-DOI on medial prefrontal cortical cells: a microiontophoretic study. Brain Res 1989; 498: 393-396.

[147] Tanaka E, North RA. Actions of 5-hydroxytryptamine on neurons of the rat cingulate cortex. J Neurophysiol 1993; 69: 1749-1757.

[148] Aghajanian GK, Marek GJ. Serotonin induces excitatory postsynaptic potentials in apical dendrites of neocortical pyramidal cells. Neuropharmacology 1997; 36: 589-599.

[149] Arvanov VL, Liang X, Magro P, Roberts R, Wang RY. A pre- and postsynaptic modulatory action of $5-\mathrm{HT}$ and the $5-\mathrm{HT}_{2 \mathrm{~A}}, 2 \mathrm{C}$ receptor agonist DOB on NMDA-evoked responses in the rat medial prefrontal cortex. Eur J Neurosci 1999; 11: 2917-2934.

[150] Zhou FM, Hablitz JJ. Activation of serotonin receptors modulates synaptic transmission in rat cerebral cortex. J Neurophysiol 1999; 82: 2989-2999.

[151] Férézou I, Cauli B, Hill EL, Rossier J, Hamel E, Lambolez B. 5-HT 3 receptors mediate serotonergic fast synaptic excitation of neocortical vasoactive intestinal peptide/cholecystokinin interneurons. J Neurosci 2002; 22: 7389-7397.

[152] Puig MV, Celada P, Díaz-Mataix L, Artigas F. In vivo modulation of the activity of pyramidal neurons in the rat medial prefrontal cortex by $5-\mathrm{HT}_{2 \mathrm{~A}}$ receptors: relationship to thalamocortical afferents. Cereb Cortex 2003; 13: 870-882.

[153] Pehek EA, Yamamoto BK. Differential effects of locally administered clozapine and haloperidol on dopamine efflux in the rat prefrontal cortex and caudate-putamen. J Neurochem 1994; 63: 2118-2124.

[154] Rollema H, Lu Y, Schmidt AW, Zorn SH. Clozapine increases dopamine release in prefrontal cortex by $5-\mathrm{HT}_{1 \mathrm{~A}}$ receptor activation. Eur $\mathrm{J}$ Pharmacol 1997; 338: R3-R5.

[155] Ichikawa J, Ishii H, Bonaccorso S, Fowler WL, O'Laughlin IA, Meltzer HY. $5-\mathrm{HT}_{2 \mathrm{~A}}$ and $\mathrm{D}_{2}$ receptor blockade increases cortical DA release via 5$\mathrm{HT}_{1 \mathrm{~A}}$ receptor activation: a possible mechanism of atypical antipsychoticinduced cortical dopamine release. J Neurochem 2001; 76: 1521-1531.

[156] Assié MB, Ravailhe V, Faucillon V, Newman-Tancredi A. Contrasting contribution of 5-hydroxytryptamine $1 \mathrm{~A}$ receptor activation to 
neurochemical profile of novel antipsychotics: frontocortical dopamine and hippocampal serotonin release in rat brain. J Pharmacol Exp Ther 2005; 315: 265-272.

[157] Bortolozzi A, Díaz-Mataix L, Toth M, Celada P, Artigas F. In vivo actions of aripiprazole on serotonergic and dopaminergic systems in rodent brain. Psychopharmacology 2007; 191: 745-758.

[158] Rollema H, Lu Y, Schmidt AW, Sprouse JS, Zorn SH. 5-HT 1 A receptor activation contributes to ziprasidone-induced dopamine release in the rat prefrontal cortex. Biol Psychiatry 2000; 48: 229-237.

[159] Kuroki T, Meltzer HY, Ichikawa J. Effects of antipsychotic drugs on extracellular dopamine levels in rat medial prefrontal cortex and nucleus accumbens. J Pharmacol Exp Ther 1999; 288: 774-781.

[160] Sumiyoshi T, Park S, Jayathilake K, Roy A, Ertugrul A, Meltzer HY. Effect of buspirone, a serotonin ${ }_{1 A}$ partial agonist, on cognitive function in schizophrenia: A randomized, double-blind, placebo-controlled study. Schizophr Res 2007; 95: 158-168.

[161] Wadenberg M-L, Hertel P, Fernholm R, Blakeman KH, Ahlenius S, Svensson TH. Enhancement of antipsychotic-like effects by combined treatment with the $\alpha_{1}$-adrenoceptor antagonist prazosin and the dopamine D2 receptor antagonist raclopride in rats. J Neural Transm 2000; 107: 1229-1238.

[162] Freund TF, Katona I. Perisomatic inhibition. Neuron 2007; 56: 33-42.

[163] Gonzalez-Burgos G, Lewis DA. GABA neurons and the mechanisms of network oscillations: implications for understanding cortical dysfunction in schizophrenia. Schizophr Bull 2008; 34: 944-961.

[164] Ahlenius S. Clozapine: dopamine $D_{1}$ receptor agonism in the prefrontal cortex as the code to decipher a Rosetta stone of antipsychotic drugs. Pharmacol Toxicol 1999; 84: 193-196.

[165] Millan MJ. N-methyl-D-aspartate receptors as a target for improved antipsychotic agents: novel insights and clinical perspectives. Psychopharmacology 2005; 179: 30-53.

[166] Newcomer JW. Second-generation (atypical) antipsychotics and metabolic effects: a comprehensive literature review. CNS Drugs 2005; 19 Suppl 1: 1-93.

[167] Leucht S, Corves C, Arbter D, Engel RR, Li C, Davis JM. Secondgeneration versus first-generation antipsychotic drugs for schizophrenia: a meta-analysis. Lancet 2009; 373: 31-41.

[168] Tamminga CA. Partial dopamine agonists in the treatment of psychosis. J Neural Transm 2002; 109: 411-420.

[169] DeLeon A, Patel NC, Crismon ML. Aripiprazole: a comprehensive review of its pharmacology, clinical efficacy, and tolerability. Clin Ther 2004; 26: 649-666.

[170] Aghajanian GK, Marek GJ. Serotonin model of schizophrenia: emerging role of glutamate mechanisms. Brain Res Brain Res Rev 2000; 31: 302312.

[171] Marek GJ. Metabotropic glutamate 2/3 receptors as drug targets. Curr Opin Pharmacol 2004; 4: 18-22.

[172] Galarreta M, Hestrin S. A network of fast-spiking cells in the neocortex connected by electrical synapses. Nature 1999; 402: 72-75. 
[173] Cruikshank SJ, Lewis TJ, Connors BW. Synaptic basis for intense thalamocortical activation of feedforward inhibitory cells in neocortex. Nat Neurosci 2007; 10: 462-468.

[174] Lewis DA, Hashimoto T, Volk DW. Cortical inhibitory neurons and schizophrenia. Nature Rev Neurosci 2005; 6: 312-3.

[175] González-Maeso J, Ang RL, Yuen T, Chan P, Weisstaub NV, LópezGiménez JF, Zhou M, Okawa Y, Callado LF, Milligan G, Gingrich JA, Filizola M, Meana JJ, Sealfon SC. Identification of a serotonin/glutamate receptor complex implicated in psychosis. Nature 2008; 452: 93-97. 
Table 1. In vitro binding affinities of the four antipsychotics used in the present study, expressed in $\mathrm{K}_{\mathrm{i}}$ values (nM).

\begin{tabular}{|l|l|l|l|l|}
\hline Receptor & Clozapine & Olanzapine & Haloperidol & Chlorpromazine \\
\hline $\mathrm{D}_{1}$ & 85 & 31 & 210 & 56 \\
\hline $\mathrm{D}_{2}$ & 125 & 11 & 1 & 2 \\
\hline $\mathrm{D}_{3}$ & 473 & 27 & 2 & 9 \\
\hline $\mathrm{D}_{4}$ & 35 & 21 & 5 & 12 \\
\hline $5-\mathrm{HT}_{1 \mathrm{~A}}$ & 770 & $>10,000$ & 2,600 & $116^{*}$ \\
\hline $5-\mathrm{HT}_{2 \mathrm{~A}}$ & 12 & 2 & 78 & 2 \\
\hline $5-\mathrm{HT}_{2 \mathrm{C}}$ & 8 & 11 & 1,500 & 25 \\
\hline$\alpha_{1}$-adrenergic & 7 & 7 & 6 & 1 \\
\hline $\mathrm{H}_{1}$ histamine & 6 & 7 & $>730$ & 9 \\
\hline Muscarinic & 2 & 2 & $>1,500$ & 60 \\
\hline
\end{tabular}

Data taken from references [44, 45, 52, 81-83].

*Data from human cloned $5-\mathrm{HT}_{1 \mathrm{~A}}$ receptors. 
Table 2. Changes in extracellular 5-HT and glutamate in the mPFC as a result of the action of intra-mPFC administration of drugs on different monoamine receptors. $(=)$ unchanged, $(\uparrow)$ increase and $(\downarrow)$ decrease.

\begin{tabular}{|c|c|c|}
\hline Receptor action & ges in 5-HT & Changes in glutamate \\
\hline$D_{2} / D_{3}$ antagonism & $=$ & $\uparrow$ \\
\hline $\mathrm{D}_{4}$ antagonism & $=$ & $\uparrow$ \\
\hline $\mathrm{D}_{1}$ agonism & $\downarrow$ & $\uparrow$ \\
\hline 5- $\mathrm{HT}_{1 \mathrm{~A}}$ agonism & $\downarrow$ & $=$ \\
\hline 5- $\mathrm{HT}_{2 \mathrm{~A}}$ antagonism & $\downarrow$ & $\uparrow$ \\
\hline$\alpha_{1}$-adrenoceptor antagonism & $\downarrow$ & $=$ \\
\hline
\end{tabular}

Data taken from reference $[60,62]$ and X. López-Gil, F. Artigas and A. Adell (unpublished results). 


\section{FIGURE LEGENDS}

Figure 1. Effects of the intra-mPFC perfusion (line) of $300 \mu \mathrm{M}$ of clozapine (CLZ), olanzapine (OLZ), chlorpromazine (CPZ) and haloperidol (HAL) on the efflux of $5-\mathrm{HT}(A)$ and glutamate (B) in the mPFC elicited by MK-801 $(1 \mathrm{mg} / \mathrm{kg}$, i.p.; arrow). Data (mean \pm SEM) are expressed as percentage changes of the four basal predrug values. Number of animals is given in parentheses. The control group received an injection of saline and, for the sake of clarity, is depicted as a dotted line. Analysis of variance (ANOVA) shows that all four antipsychotic drugs block the increase in glutamate produced by MK-801, but only clozapine and olanzapine are able to block the effect of MK-801 on 5-HT.

Figure 2. Effects of the perfusion of the dopamine $D_{2} / D_{3}$ antagonist raclopride (RAC, 10, 30 and $100 \mu \mathrm{M}$ ) on the efflux of $5-\mathrm{HT}(\mathrm{A})$ and glutamate $(B)$ in the mPFC elicited by MK-801 (1 mg/kg, i.p.; arrow). Data are based on integrated area under the curve (AUC) analysis of 4-h perfusion, and expressed as the percentage change from the control group depicted as open bar. ${ }^{*} p<0.01$ vs. control group and $\S_{p}<0.01$ vs. MK-801 alone (Newman-Keuls test following ANOVA).

Figure 3. Effects of the perfusion of the selective dopamine $D_{4}$ antagonist $L-$ $745,870(\mathrm{~L}, 10$ and $30 \mu \mathrm{M})$ on the efflux of $5-\mathrm{HT}(\mathrm{A})$ and glutamate $(\mathrm{B})$ in the mPFC elicited by MK-801 (1 mg/kg, i.p.; arrow). Data are based on integrated area under the curve (AUC) analysis of 4-h perfusion, and expressed as the percentage change from the control group depicted as open bar. ${ }^{*} p<0.01$ vs. control group and ${ }^{\S} p<0.01$ vs. MK-801 alone (Newman-Keuls test following ANOVA).

Figure 4. Effects of the perfusion of the dopamine $D_{1} / D_{5}$ agonist SKF 38393 (SKF, 1, 10 and $100 \mu \mathrm{M}$ ) on the efflux of $5-\mathrm{HT}(\mathrm{A})$ and glutamate $(\mathrm{B})$ in the mPFC elicited by MK-801 (1 mg/kg, i.p.; arrow). Data are based on integrated area under the curve (AUC) analysis of 4-h perfusion, and expressed as the percentage change from the control group depicted as open bar. ${ }^{*} p<0.01$ vs. 
control group and $\S_{p}<0.01$ vs. MK-801 alone (Newman-Keuls test following ANOVA).

Figure 5. Effects of the perfusion of the selective $5-\mathrm{HT}_{2 \mathrm{~A}}$ antagonist $\mathrm{M} 100907$ $(\mathrm{M}, 1,10$ and $300 \mu \mathrm{M})$ on the efflux of $5-\mathrm{HT}(\mathrm{A})$ and glutamate $(B)$ in the mPFC elicited by MK-801 (1 mg/kg, i.p.; arrow). Data are based on integrated area under the curve (AUC) analysis of 4-h perfusion, and expressed as the percentage change from the control group depicted as open bar. ${ }^{*} p<0.01$ vs. control group and ${ }^{\S_{p}}<0.01$ vs. MK-801 alone (Newman-Keuls test following ANOVA).

Figure 6. Effects of the perfusion of the selective $5-\mathrm{HT}_{1 \mathrm{~A}}$ agonist repinotan (BAY $\times 3702$; BAY, 1 and $30 \mu \mathrm{M}$ ) on the efflux of $5-\mathrm{HT}(\mathrm{A})$ and glutamate $(\mathrm{B})$ in the mPFC elicited by MK-801 (1 mg/kg, i.p.; arrow). Data are based on integrated area under the curve (AUC) analysis of 4-h perfusion, and expressed as the percentage change from the control group depicted as open bar. ${ }^{*} p<$ 0.01 vs. control group and $\S_{p}<0.01$ vs. MK-801 alone (Newman-Keuls test following ANOVA). Data taken and redrawn from reference [62], with permission.

Figure 7. Effects of the perfusion of the selective $\alpha_{1}$-adrenoceptor antagonist prazosin (PRZ, 1, 10 and $100 \mu \mathrm{M})$ on the efflux of $5-\mathrm{HT}(\mathrm{A})$ and glutamate (B) in the mPFC elicited by MK-801 (1 mg/kg, i.p.; arrow). Data are based on integrated area under the curve (AUC) analysis of 4-h perfusion, and expressed as the percentage change from the control group depicted as open bar. ${ }^{*} p<$ 0.01 vs. control group and ${ }^{\S} \mathrm{p}<0.01$ vs. MK-801 alone (Newman-Keuls test following ANOVA).

Figure 8. The diagram illustrates the functional relationships between the mPFC and its dopaminergic and serotonergic projections from the VTA and the $D R$, respectively. Although all monoaminergic receptors depicted in this figure are present in both pyramidal cells and GABAergic interneurons, it is only 
represented the localization that conforms to the results obtained in the present study. 


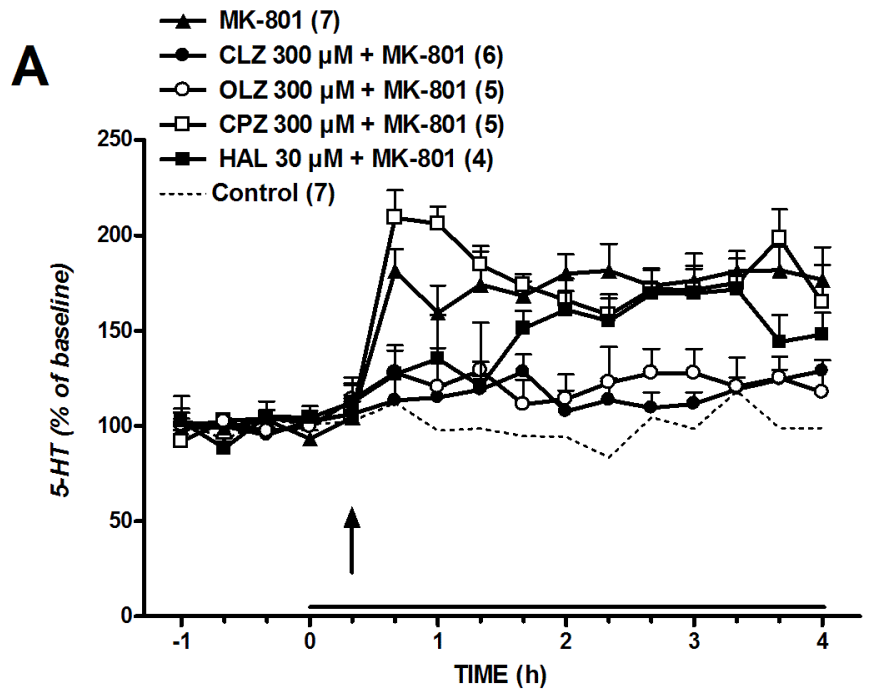

B

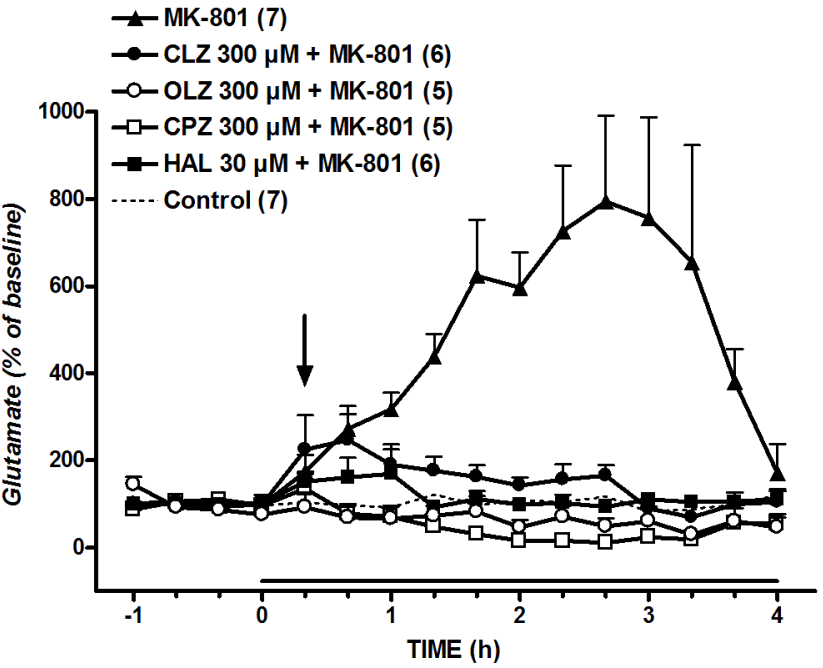


A

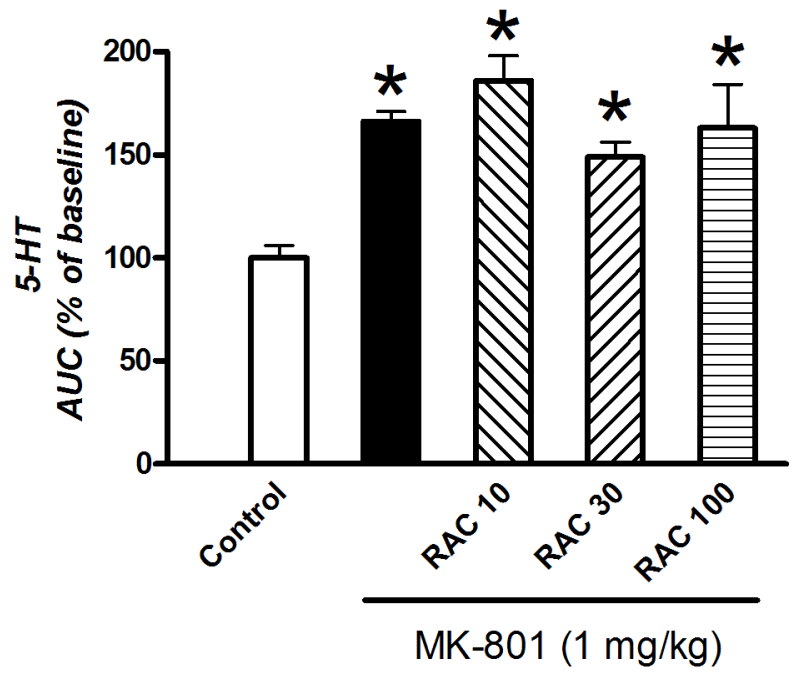

B

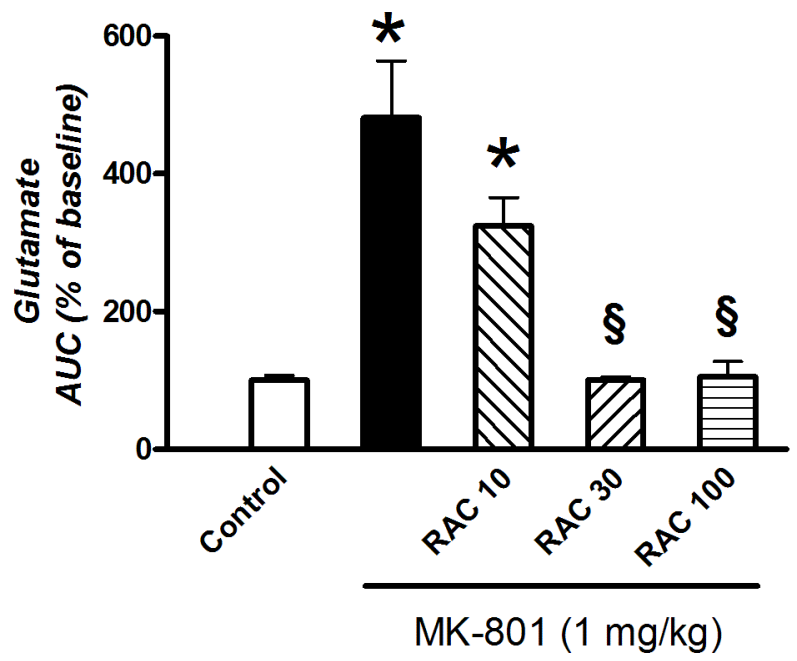


A

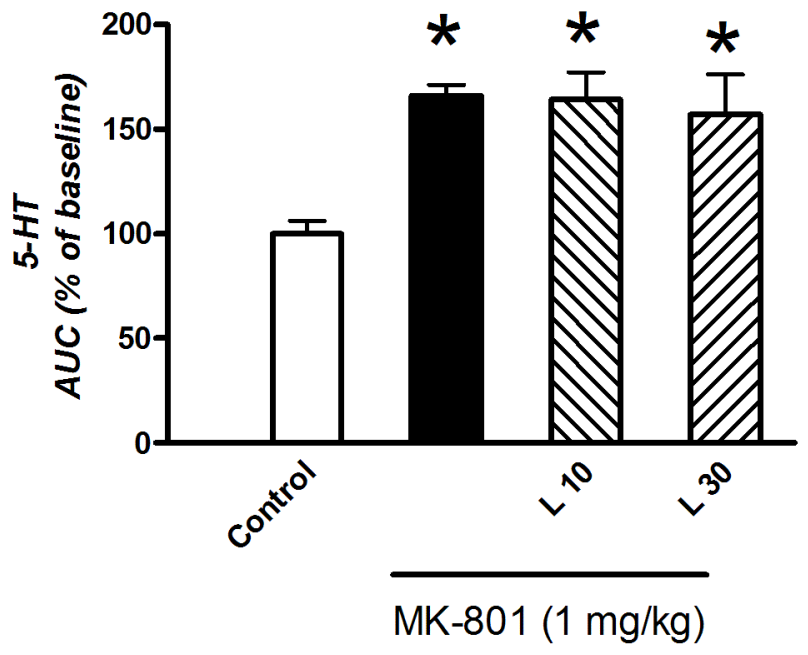

B

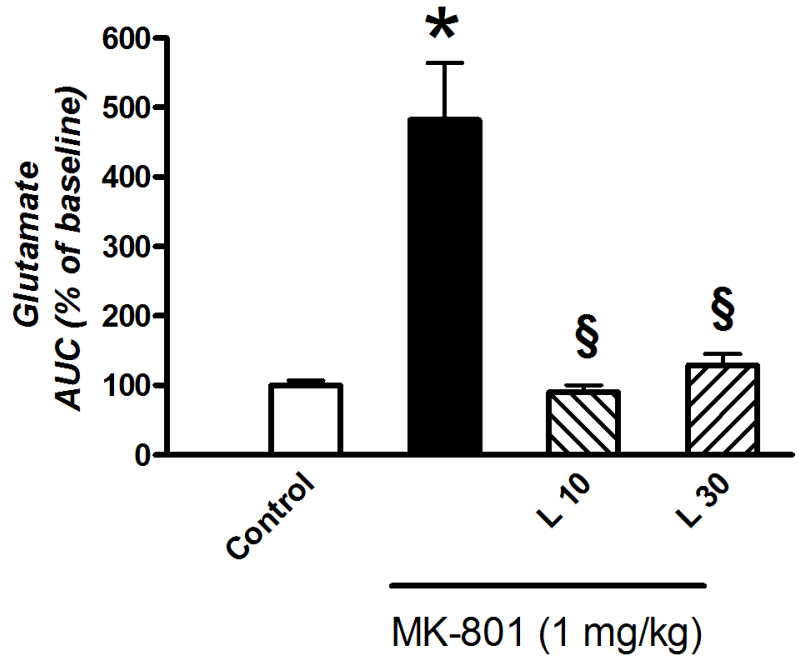


A

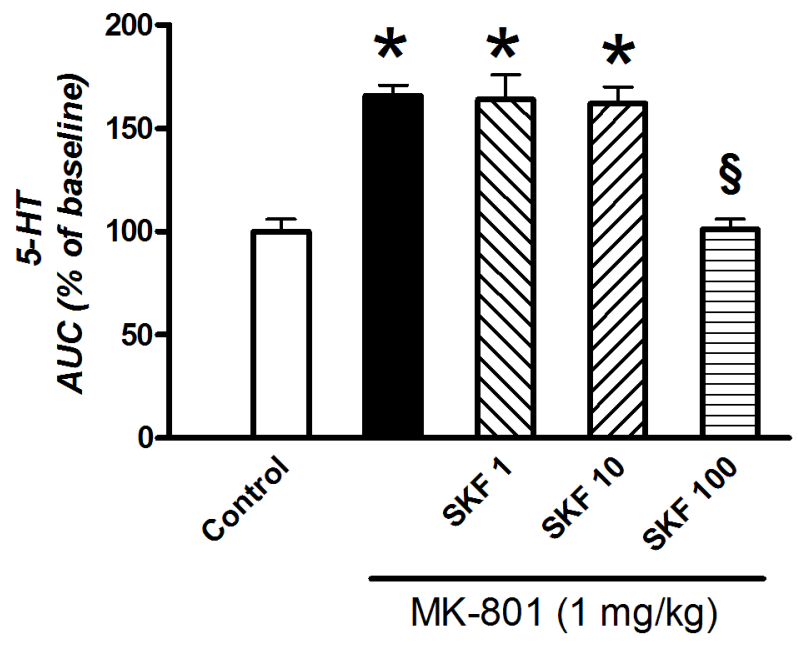

B

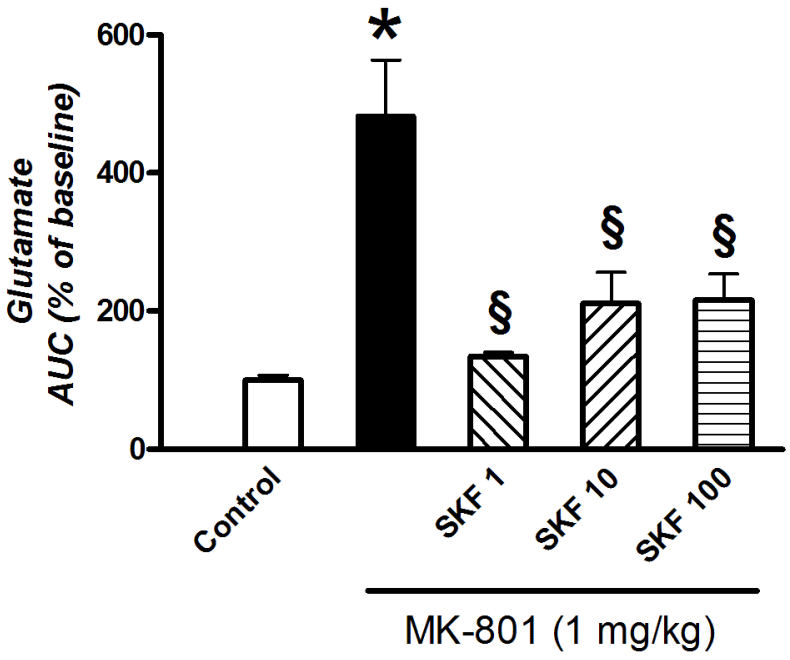


A

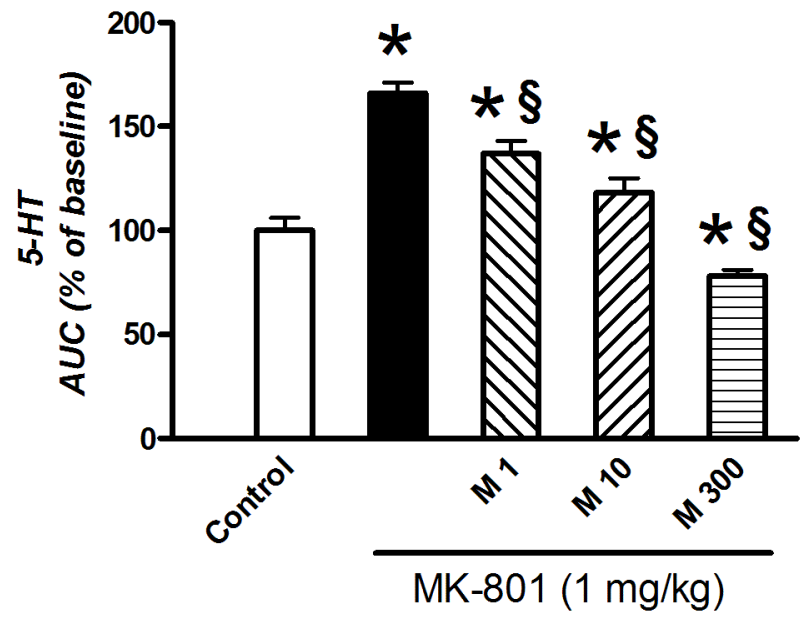

B

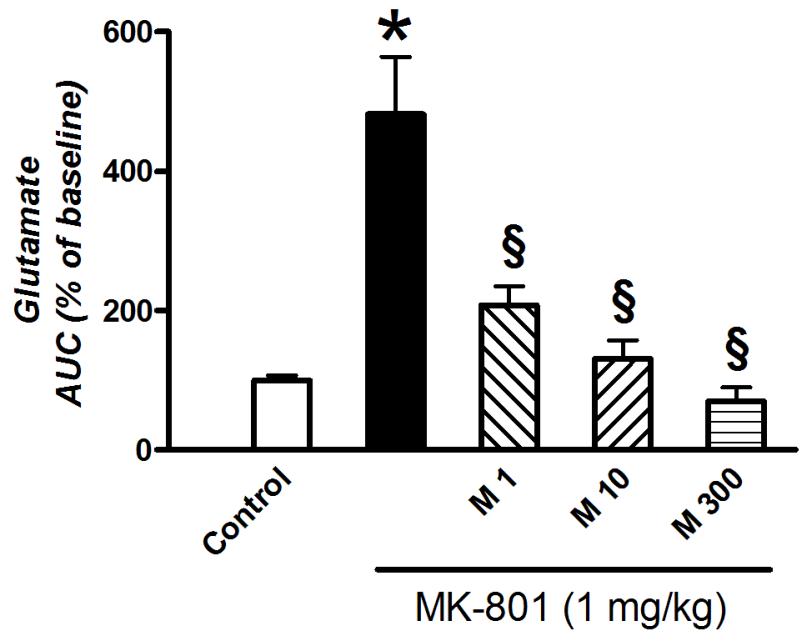


A

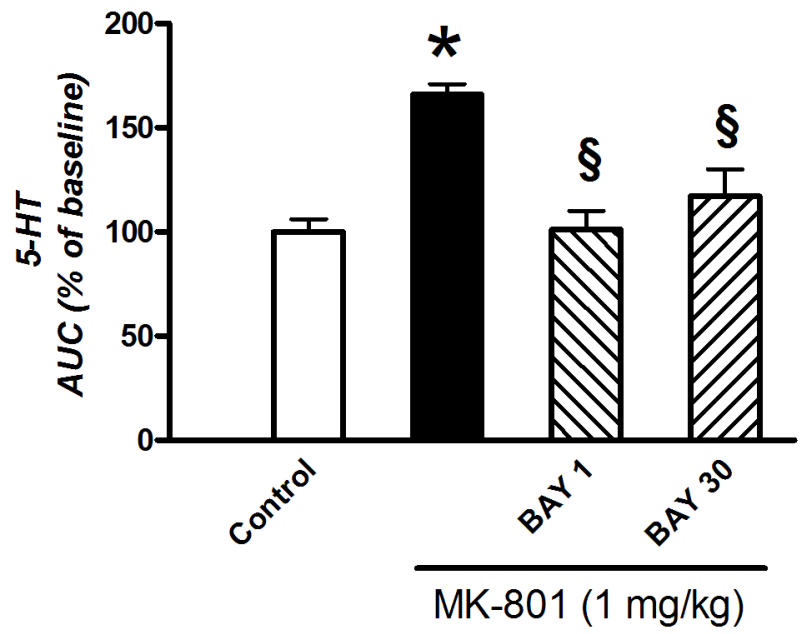

B

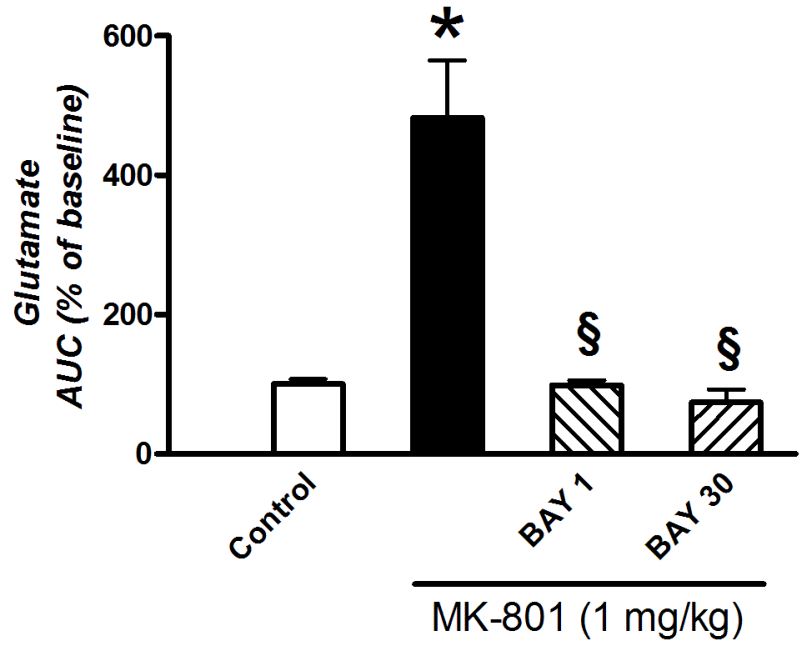


A

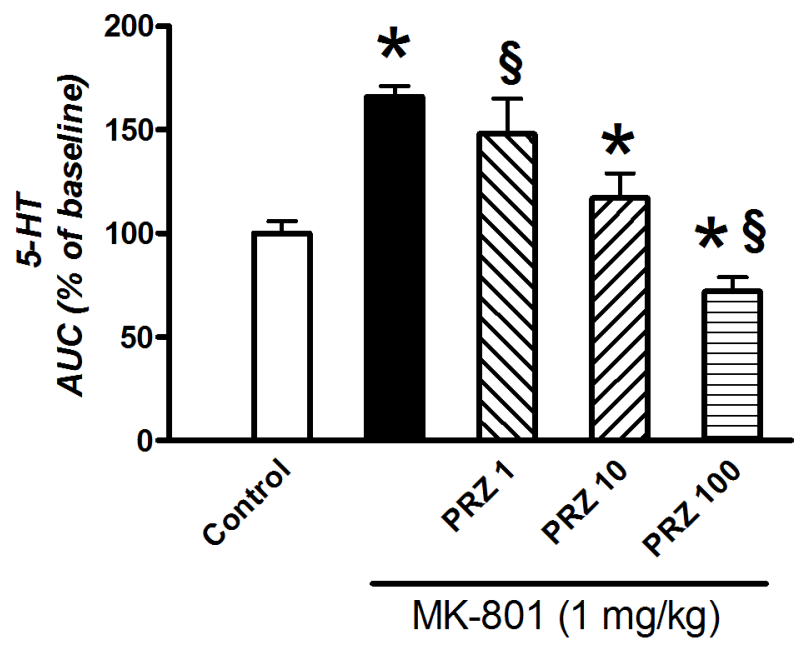

B

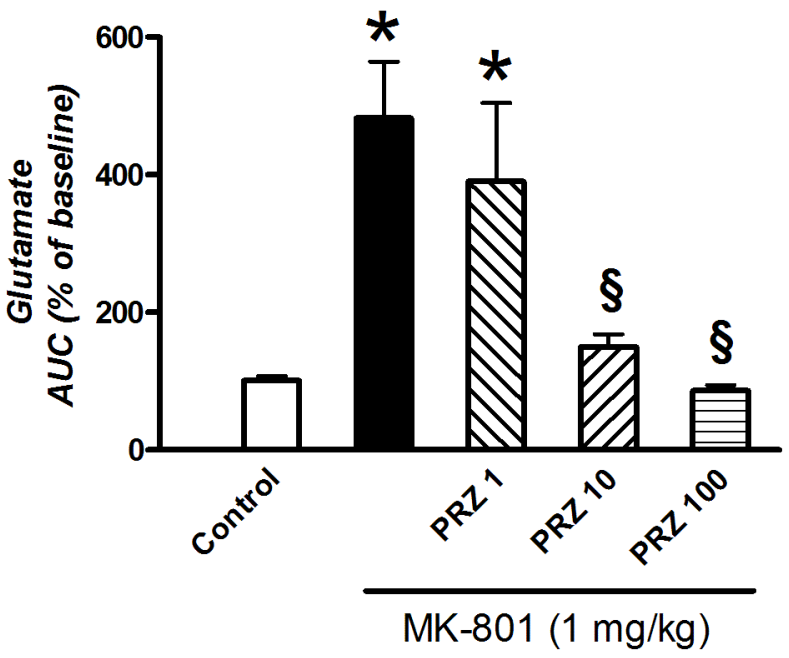


